Nova Southeastern University

Florida

NSUWorks

Faculty Scholarship

Shepard Broad College of Law

Spring 1-1-2008

\title{
What if DRM Fails?: Seeking Patronage in the iWasteland and the Virtual 0
}

Jon M. Garon

Follow this and additional works at: https://nsuworks.nova.edu/law_facarticles

\section{Recommended Citation}

Jon M. Garon, What if DRM Fails?: Seeking Patronage in the iWasteland and the Virtual 0, $2008 \mathrm{MICH}$. STATE L. REV. 103 (2008).

This Article is brought to you for free and open access by the Shepard Broad College of Law at NSUWorks. It has been accepted for inclusion in Faculty Scholarship by an authorized administrator of NSUWorks. For more information, please contact nsuworks@nova.edu. 


\section{Michigan State LAW REVIEW}

\section{TABLE OF CONTENTS}

\section{What Ifs and Other Alternative Intellectual Property and Cyberlaw Stories}

What Ifs and Other Alternative Intellectual Property and Cyberlaw Stories: Foreword

Peter K. Yu

What If Every "If Only" Statement Were True?: The Logic of Counterfactuals

Kevin W. Saunders.

Ignoring Patents

Mark A. Lemley.....

What If Samuel D. Warren Hadn't Married a Senator's Daughter?: Uncovering the Press Coverage That Led to "The Right to Privacy"

Amy Gajda 35

The Internet and Pornography: What If Congress and the Supreme Court Had Been Comprised of Techies in 1995-1997?

Cheryl B. Preston.

What If DRM Fails?: Seeking Patronage in the iWasteland and the Virtual O Jon M. Garon.

What If the Anti-Bootlegging Statutes Are Upheld Under the Commerce Clause?

Michael Landau

What If Object Code Had Been Excluded from Protection as a Literary Work in Copyright Law? A New Zealand Perspective

Susan Corbett.

Authorship as Public Address: On the Specificity of Copyright Vis-à-vis Patent and Trade-Mark

Abraham Drassinower

What If Employees Owned Their Copyrights?

Deborah Tussey 
What If There Were a Business Method Use Exemption to Patent Infringement? Katherine J. Strandburg.....................................................................245

Claiming Copyleft in Open Source Software: What If the Free Software

Foundation's General Public License (GPL) Had Been Patented?

Greg R. Vetter.

What If Seeds Were Not Patentable?

Elizabeth I. Winston

What If, After All, Trademarks Were "Traded in Gross"?

Irene Calboli

The Lingering Legacy of Trade-mark Cases

John T. Cross

What If ... the Stud Does Not Function?

Peter Bowal \& Christopher Bowal

What If James Madison Were to Assess the Intellectual Property Revolution? Liam Séamus O'Melinn

The Past, Present, and Future of Computing and Its Impact on Digital Rights Management

M. Scott Boone. 


\title{
WHAT IF DRM FAILS?: SEEKING PATRONAGE IN THE IWASTELAND AND THE VIRTUAL O
}

\author{
Jon M. Garon * \\ 2008 MICH. ST. L. REV. 103
}

TABLE OF CONTENTS

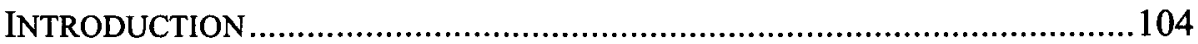

I. THE CODIFICATION OF ANTICIRCUMVISION ........................................106

A. Changing International Law to Revise Domestic Law...............107

B. No Admittance-The DMCA's Role as Back Stage Bouncer ....108

C. Undermining Rights Management: Using the DMCA to Block Competition-Corporate Misuse of Anticircumvention for Anticompetitive Tricks ..........................................................115

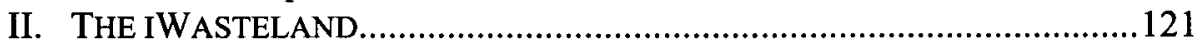

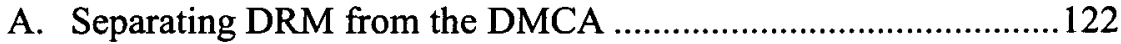

B. Copyright as an Engine for Opportunity ................................127

III. Patronage Revisited-Is EVERything Old NeW AgaIN? ............131

A. Revisiting the Economic Underpinnings of Entertainment .........132

B. Balancing the Models for Entertainment Funding......................136

C. Expropriating Patrons-Ownership by EULA .............................137

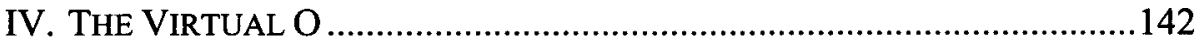

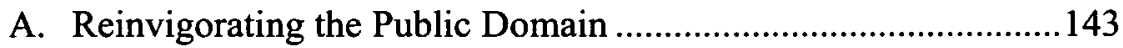

B. Embracing Open Source Art....................................................145

C. The Brave New World of the Virtual O ....................................148

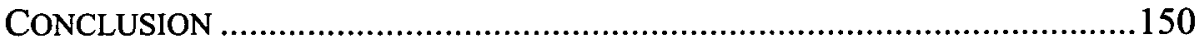

Can this cockpit hold The vasty fields of France? Or may we cram Within this Wooden $O$ the very casques That did affright the air at Agincourt?

- Henry V, Prologue

Imagine a world where every online store sells DRM-free music encoded in open licensable formats. In such a world, any player can play music pur-

* Dean and Professor of Law, Hamline University School of Law; J.D. Columbia 1988. This Article was originally developed at the 4th Annual Intellectual Property and Communications Law Program Symposium: What Ifs and Other Alternative Intellectual Property and Cyberlaw Stories, Michigan State University College of Law, Mar. 30-31, 2007, and the Oct. 17, 2006 Midwest IP Seminar. I would like to thank Professor Peter Yu and the many colleagues who have commented on previous versions of this Article. 
chased from any store, and any store can sell music which is playable on all players. This is clearly the best alternative for consumers, and Apple would embrace it in a heartbeat.

-Steve Jobs ${ }^{1}$

\section{INTRODUCTION}

Section 1201 of the landmark 1998 Digital Millennium Copyright $\mathrm{Act}^{2}$ (DMCA) provided sweeping protection for technological measures or "virtual locks" on digital content to protect the entertainment industriesincluding music, films, games, and consumer electronics. Manufacturers use digital rights management (DRM) authorized under the law to lock down all software embedded in products, movies on DVDs, and audio files sold on iTunes and other Intemet sites. Critics of the DMCA have charged that the law has extended well past its anti-piracy role to undermine fair use, threaten free speech, and thwart product interoperability. Critics of DRM complain that DRM unfairly extends copyright and that legal protection is unnecessary to the robust development of new creative works.

This Article reviews the difficulties of the DMCA implementation, focusing on the implications of a marketplace in which DRM fails either as a result of technological countermeasures or statutory change. After reviewing the legal history of the DMCA, however, I hope to bring the potential implications of the DMCA backlash into focus by emphasizing the need to protect the author working in the modern digital medium.

The DMCA is a relatively short but highly significant group of statutory amendments to the Copyright Act, which included the World Intellectual Property Organization (WIPO) Copyright Treaty and Performances and Phonograms Treaty implementation, copyright safe harbor provisions involving computer maintenance and transitory server copies of music, and the Copyright Protection and Management Systems. ${ }^{3}$ Section 1201, the copyright protection portion of the Act, is generally referred to as "the DMCA." Section 1201 is the provision that focuses most heavily on the technological and legal "code" battle over the digitization of entertainment and media content. ${ }^{4}$

The code battle highlights the tension over the locus of regulatory control. Does statutory code control the behavior of the public, or does the

1. Steve Jobs, Thoughts on Music (Feb. 6, 2007), http://www.apple.com/hotnews/thoughtsonmusic/.

2. Pub. L. No. 105-304, 112 Stat. 2860 (1998).

3. Id.

4. See Dan L. Burk, Panel IV: Market Regulation and Innovation: Legal and Technical Standards in Digital Rights Management Technology, 74 FORDHAM L. REV. 537, 546 (2005). See generally LAWRENCE LESSIG, CODE AND OTHER LAWS OF CYBERSPACE (1999). 
computer code serve as the primary source of consumer behavior control? ${ }^{5}$ Underlying this dichotomy is the need to reduce piracy and intellectual property theft, as well as the need to positively respond to the increasingly interactive nature of the consumer. Authors and distributors should have the right to control the distribution of their products. ${ }^{6}$ The public has an expectation that ownership of copies of a work carries with it the right to use or abuse the particular copy of the work owned. ${ }^{7}$ Moreover, websites such as Myspace.com and YouTube.com demonstrate that the availability of interactive technology has changed the relationship between author and audience, perhaps radically transforming the expectations of what is "fair" under the classical notions of fair use.

Professor Peter $\mathrm{Yu}$ identifies the analysis of DRM as a debate with two polar positions. "In today's DRM debate, there are generally two different camps. While rights holders, their investors and representatives are on one side, academics (usually liberal academics), consumer advocates, and civil libertarians are on the other." 8 Although an academic, I side with the artists and their corporate enablers because I would prefer the policy balance to foster creativity instead of access. Nonetheless, in fairness, I should also recognize my own consumer habits. I love my digital video recorder (DVR) and fast-forward through most over-the-air commercials; I detest DVDs that do not allow the viewer to skip previews; and the audio books I keep on hand both in my car and on my phone come from the public library rather than a for-profit vendor. My consumer behaviors seem typical of a public that finds DRM an annoyance and distrusts media corporations that seek to impose advertising or usage patterns as a condition of its media consumption.

Embedded in the debate are philosophical assumptions about the role of copyright to incentivize authors, musicians, artists, and other creators, ${ }^{9}$ as

5. I have written elsewhere that this dichotomy ignores the more important normative or social code inherent in copyright policy. See Jon M. Garon, Normative Copyright: $A$ Conceptual Framework for Copyright Philosophy and Ethics, 88 CORNELL L. REV. 1278, 1339 (2003).

6. 17 U.S.C. $\S 106(2000)$.

7. Id. $\S 109$.

8. Peter K. Yu, Anticircumvention and Anti-anticircumvention, 84 DENV. U. L. REV. 13, 16 (2006).

9. The Supreme Court in Eldred v. Ashcroft, 537 U.S. 186 (2003), amply illustrated the debate. Compare the majority opinion:

As we have explained, "[t]he economic philosophy behind the [Copyright] [C]lause .... is the conviction that encouragement of individual effort by personal gain is the best way to advance public welfare through the talents of authors and inventors." Accordingly, "copyright law celebrates the profit motive, recognizing that the incentive to profit from the exploitation of copyrights will redound to the public benefit by resulting in the proliferation of knowledge. ... The profit motive is the engine that ensures the progress of science." 
well as the role of law, technology, and social norms to enforce the customs of copyright protection. ${ }^{10}$ Increasingly, the debate has moved from the role of copyright itself to the technological implications of the policy and the strategies for enforcing the policy. ${ }^{11}$ To the extent this Article conflates the health of copyright with the ability to enforce authors' rights ${ }^{12}$ using DRM, this Article suffers from some of those same limitations. I try, therefore, first to explain the arenas where the DMCA has benefited and hindered the broader cause of copyright. Nonetheless, I also look at the implications of copyright in the absence of technological measures for enforcement to see if there is any incentive left in the copyright regime.

\section{THE CODIFICATION OF ANTICIRCUMVISION}

Professor $\mathrm{Yu}$ readily points out that the two sides "agree on many issues, and their positions are not irreconcilable."13 Instead of an absolutist battle, the debate should more properly focus on the developing balance between the positions. Given my personal dislike of limitations imposed on copyrighted works by the distributors for embedded commercials or dis-

Id. at 212 n.18 (citations omitted) (quoting Mazer v. Stein, 347 U.S. 201, 219 (1954); Am. Geophysical Union v. Texaco Inc., 802 F. Supp. 1, 27 (S.D.N.Y. 1992), aff'd, 60 F.3d 913 (2d Cir. 1994)), with the dissent of Justice Breyer:

"Under the U.S. Constitution, the primary objective of copyright law is not to reward the author, but rather to secure for the public the benefits derived from the authors' labors. By giving authors an incentive to create, the public benefits in two ways: when the original expression is created and . . when the limited term ... expires and the creation is added to the public domain."

For present purposes, then, we should take the following as well established: that copyright statutes must serve public, not private, ends; that they must seek "to promote the Progress" of knowledge and learning; and that they must do so both by creating incentives for authors to produce and by removing the related restrictions on dissemination after expiration of a copyright's "limited Tim[e]"- a time that (like "a limited monarch") is "restrain[ed]" and "circumscribe[d]," "not [left] at large[.]"

Id. at 247-48 (Breyer, J., dissenting) (citations omitted) (quoting H.R. Rep. No. 100-609, at 17 (1988); 2 S. JOHNSON, A DictionaRY OF THE ENGLISH LANGUAGE 1151 (4th rev. ed. 1773)).

10. See Garon, supra note 5, at 1360 ("The central task, then, is to reverse Internet anarchy through a combination of education, technology and law, shaping each in concert with the others so that the copyright balance can be restored and ownership respected, while maintaining the important role of the public domain, fair use, and reverse engineering.").

11. See, e.g., Julie E. Cohen, Pervasively Distributed Copyright Enforcement, 95 GEO. L.J. 1 (2006).

12. As used herein, author rights include the rights of all authors, writers, artists, and others whose work is protected by copyright. The term should not connote a preference for one artistic form over another.

13. Yu, supra note 8 , at 16 . 
abled fast-forward buttons, I am quick to sympathize with the pro-consumer civil libertarians (or more properly, conscientious objectors).

Caught up in the tension between the content distributors and changing public expectations, the anticircumvention provisions became a social lightning rod in the clash of ideologies and expectations. As in any ideological debate, there may never be an objectively accurate synthesis, so this Article will instead modestly attempt to provide a centrist history of Section 1201 and outline its continuing impact on the reshaping of technology, entertainment, and media content.

\title{
A. Changing International Law to Revise Domestic Law
}

Section 1201 is a codification of treaty obligations enacted in the WIPO Copyright Treaty and WIPO Performances and Phonograms Treaty. Article 11 of the WIPO Copyright Treaty provides that

\begin{abstract}
Contracting Parties shall provide adequate legal protection and effective legal remedies against the circumvention of effective technological measures that are used by authors in connection with the exercise of their rights under this Treaty or the Berne Convention and that restrict acts, in respect of their works, which are not authorized by the authors concerned or permitted by law. ${ }^{14}$
\end{abstract}

Nonetheless, candor requires us to acknowledge that the international obligations are a somewhat spurious rationale because the U.S. intellectual property industry set the international agenda. As copyright expert David Nimmer explained, '[d] espite the formal rule of 'one nation, one vote,' U.S. participation in Geneva was actually massive. ... Los Angeles represents the quintessence of the United States. California's status as the seat of the Hollywood studios, the record industry and Silicon Valley all cement its status at the cynosure."15

As a result, the U.S. content industries created an international need for adequate legal protection against the circumvention of effective technological measures for online content or content digitally encrypted. The need for such international protection was legitimate. Digital protection of content was seen as a powerful tool to help open markets in which copyright piracy is otherwise rampant and where court systems are inadequate to address even rudimentary legal protection. The "effective legal remedies"

14. World Intellectual Property Organization: Copyright Treaty art. 11, Dec. 20, 1996, S. TREATY DOC. No. 105-17 (1997), 36 I.L.M. 76, available at http:/www.wipo.int/treaties/en/ip/wct/trtdocs_wo033.html\#P-87_12240.

15. David Nimmer, Time and Space, 38 IDEA 501, 508-09 (1998). See also David Nimmer, A Tale of Two Treaties, 22 ColuM.-VLA J.L. \& ARTS 1 (1997); David Nimmer, Aus der Neuen Welt, 93 Nw. U. L. REV. 195, 196-97 (1998). These three articles reflect on the adoption of the WIPO treaties. 
provision was designed to encourage signatories to take their copyright enforcement obligations seriously.

Of course, the 1996 view of the world could not fully fathom the systematic change wrought by the Internet. ${ }^{16}$ In explaining the history of the legislation, the Second Circuit explained: "Fearful that the ease with which pirates could copy and distribute a copyrightable work in digital form was overwhelming the capacity of conventional copyright enforcement to find and enjoin unlawfully copied material, Congress sought to combat copyright piracy in its earlier stages, before the work was even copied." 17 The assumption in 1996 was that strong encryption would greatly limit who had access to piracy tools so that the small number of sophisticated pirates could be effectively identified and arrested. ${ }^{18}$

Section 1201 was enacted to comply with the obligations of the WIPO Copyright Treaty by addressing three distinct types of anticircumvention infringement. The first provision, Section 1201(a)(1)(A), protects a work's security from unauthorized decryption or, in other words, bans picking any virtual lock. "No person shall circumvent a technological measure that effectively controls access to a [copyrighted] work ...."19

The second provision, Section 1201(a)(2), prohibits trafficking in black box technology or more formally, technology "produced for the purpose of circumventing a technological measure that effectively controls access to a [copyrighted] work ...."

The third provision, Section 1201(b)(1), prohibits trafficking in anticircumvention technologies "that allow some forms of 'access' but restrict other uses of the copyrighted work ...."1 Section 1201(b)(1) would therefore apply to the situation in which an Internet streaming audio player was tweaked or circumvented to permit the downloading of that content.

\section{B. No Admittance--The DMCA's Role as Back Stage Bouncer}

The anticircumvention provision and the two anti-trafficking provisions are explicitly designed to protect digital movies, music, software, and games protected by encryption. "Prior to the DMCA, a copyright owner 2000).

16. See Universal City Studios, Inc. v. Reimerdes, 111 F. Supp. 2 d 294 (S.D.N.Y.

17. Universal City Studios, Inc. v. Corley, 273 F.3d 429, 435 (2d Cir. 2001), aff'g Reimerdes, 111 F. Supp. $2 \mathrm{~d} 346$.

18. See Pamela Samuelson, Intellectual Property and the Digital Economy: Why the Anti-Circumvention Regulations Need to Be Revised, 14 BERKELEY TECH. L.J. 519, 522-23 (1999).

19. 17 U.S.C. $\S 1201(a)(1)(A)(2000)$.

20. Id. $\S 1201(\mathrm{a})(2)(\mathrm{A})$.

21. Lexmark Int'l, Inc. v. Static Control Components, Inc., 387 F.3d 522, 545 (6th Cir. 2004). 
would have had no cause of action against anyone who circumvented any sort of technological control, but did not infringe. The DMCA rebalanced these interests to favor the copyright owner; the DMCA created circumvention liability for 'digital trespass' under $\S 1201(a)(1) . " 22$ While circumventing a technology without some unauthorized copying of the encryption or intermediary copying may be difficult, the evidence of such infringement would be problematic and costly to produce. The evidence that a program or device circumvents a technological measure is self-evident by its operations.

The legal fight that framed the debate over the DMCA's scope began with Universal City Studios, Inc. $v$. Reimerdes, ${ }^{23}$ involving the Content Scramble System (CSS) adopted by the motion picture studios to standardize and enhance the encryption for DVDs. ${ }^{24}$ Reimerdes and a second defendant subsequently were settled out of the lawsuit, while Eric Corley and his hacker magazine and website continued the litigation through appeal. ${ }^{25}$

The computer program in question in Reimerdes was precisely the type of software for which the statute was enacted. DeCSS, the name of the program, allowed for the decryption of the CSS encryption used to protect DVDs so they could be copied onto computer hard drives and, through use of compression software, traded on the Internet. ${ }^{26}$ The motion picture studios coordinated their response through the Motion Picture Association of America (MPAA) to stop the posting of the software.

Legally, the MPAA was successful. The Second Circuit upheld the constitutionality of the law, including the ability to compel a takedown of both the DeCSS and links to other sites where the software was available. ${ }^{27}$ The Court identified the decryption software as a violation of both the anticircumvention provision of Section 1201(a)(1) and the anti-trafficking provision of Section 1201(a)(2). The case was a very important win for the MPAA because without court legitimacy, its efforts at thwarting piracy would be much more difficult. With a victory in hand, the organization was able to demand that websites and web hosts remove the decryption software.

Although the outcome of the case was precisely what Congress had intended, a great deal of consternation and debate regarding the litigation arose. The defendants had argued that there was a need for DeCSS because

22. Chamberlain Group, Inc. v. Skylink Techs., Inc., 381 F.3d 1178, 1195-96 (Fed. Cir. 2004).

23. 111 F. Supp. 2d 294 (S.D.N.Y. 2000).

24. Universal City Studios, Inc. v. Corley, 273 F.3d 429, 436-37 (2d Cir. 2001).

25. Reimerdes, 111 F. Supp. 2d at 346.

26. Corley, 273 F.3d at 438. See Xiaomin Huang, Peter Radkowski III \& Peter Roman, Computer Crimes, 44 AM. CRIM. L. REV. 285 (2007).

27. Corley, 273 F.3d at $455-56$. 
no DVD viewing software had been licensed for Linux, the open source computer operating system. Given that the nature of open source software would have had the effect of publishing the encryption key for CSS, the complaint was accurate. The political effect was to rally the open source community around the plaintiffs and paint the MPAA as a litigious bully no different than the Recording Industry Association of America (RIAA). The legitimacy of the complaint, however, was irrelevant, since it would never have been a reasonable fair use claim to give away the encryption code in an effort to service a market intentionally avoided by the copyright holder.

Added to the polemic nature of online debate was the nature of the injunctive relief. Both the software program and the code for DeCSS had been posted on the Internet so that they were freely available. The more attention provided to the litigation, the more mirror sites added links to the software. The Reimerdes Court enjoined more than the posting of and trafficking in DeCSS. ${ }^{28}$ The district court focused heavily on the extent to which a ban on the encryption software itself limited the free expression of the defendants. The district court treated the statute as content-neutral, focusing on the effects of the circumvention software rather than its communicative nature, and relied on the same types of constitutional ordinances that restrict adult theatres. ${ }^{29}$

Acknowledging that the defendants were linking to third-party sites in order to continue encouraging the distribution of DeCSS, the district court attempted to create a substantially higher standard for enjoining linking. ${ }^{30}$ It likened the heightened standard to that of New York Times Co. v. Sullivan, ${ }^{31}$ creating a standard that would exclude all uses but those intentionally abetting circumvention. Of course, the defendants had exceeded this standard:

[P]laintiffs have established by clear and convincing evidence that these defendants linked to sites posting DeCSS, knowing that it was a circumvention device. Indeed, they initially touted it as a way to get free movies, and they later maintained

28. Reimerdes, 111 F. Supp. 2d at 294.

29. Id. at 329 (citing City of Renton v. Playtime Theatres, Inc., 475 U.S. 41 (1986)) ("As Congress' concerns in enacting the anti-trafficking provision of the DMCA were to suppress copyright piracy and infringement and to promote the availability of copyrighted works in digital form, and not to regulate the expression of ideas that might be inherent in particular anti-circumvention devices or technology, this provision of the statute properly is viewed as content neutral.").

30. Id. at 341 ("[T]here may be no injunction against, nor liability for, linking to a site containing circumvention technology, the offering of which is unlawful under the DMCA, absent clear and convincing evidence that those responsible for the link (a) know at the relevant time that the offending material is on the linked-to site, (b) know that it is circumvention technology that may not lawfully be offered, and (c) create or maintain the link for the purpose of disseminating that technology.").

31. 376 U.S. 254 (1964). 
the links to promote the dissemination of the program in an effort to defeat effective judicial relief. ${ }^{32}$

Nonetheless, the links to DeCSS remained easy to find through search engines. The attempt to thwart access to DeCSS by enjoining only the named plaintiffs had no effect, other than to encourage more postings and links to the software. The court's barring of the plaintiff's right to publish an Internet address also seemed heavy-handed, notwithstanding the thoughtful analysis that went into the opinion. Outside of the media industries, my admittedly unscientific review of computer magazines and intellectual property literature suggested that the opinion was not well understood and was largely disliked.

Despite the lack of popularity, the decision has helped the MPAA and the efforts to reduce piracy. Since the Reimerdes/Corley decision, all subsequent courts have reinforced the basic presumptions that the use or sale of black boxes and software programs to circumvent encryption are unlawful. ${ }^{33}$ Although the courts are showing some appropriate restraint in the use of Section 1201 by tying it directly to the protection of copyrighted works, ${ }^{34}$ they have not weakened the shield provided to content distributors.

The DeCSS litigation has forged a legal shield for the distributors of software and entertainment content. With robust decisions outlawing software black boxes, the jurisprudence removes the political and social debate regarding the "rights" of consumers to back up their DVDs. Academic and journalistic claims that Congress could not legally limit the ways in which a consumer uses a copy of a DVD seem to have diminished in the wake of the decision.

The U.S. Supreme Court decision in Metro Goldwyn Mayer Studios Inc. v. Grokster, Ltd., ${ }^{35}$ further reinforced this trend by finding third-party copyright liability for the inducement of copyright infringement. ${ }^{36}$ Many of the academic and industry leaders awaited the Grokster decision to clarify the debate regarding the scope of the safe harbor first articulated in Sony

32. Reimerdes, 111 F. Supp. 2d at 341 (footnote omitted).

33. E.g., Davidson \& Assocs. v. Jung, 422 F.3d 630 (8th Cir. 2006); 321 Studios v. Metro Goldwyn Mayer Studios, Inc., 307 F. Supp. 2d 1085, 1095 (N.D. Cal. 2004) (CSS); Pearl Invs., LLC v. Standard VO, Inc., 257 F. Supp. 2d 326, 349-50 (D. Me. 2003) (virtual private network); RealNetworks, Inc. v. Streambox, Inc., No. C99-2070P, 2000 U.S. Dist. LEXIS 1889 (W.D. Wash. Jan. 18, 2000); Sony Computer Entm't Am. Inc. v. Gamemasters, 87 F. Supp. 2d 976, 987 (N.D. Cal. 1999) (PlayStation game console CD-ROM).

34. Storage Tech. Corp. v. Custom Hardware Eng'g \& Consulting, Inc., 421 F.3d 1307, 1318 (Fed. Cir. 2005), reh'g denied, 431 F.3d 1374 (Fed. Cir. 2005); Chamberlain Group, Inc. v. Skylink Technologies, Inc., 381 F.3d 1178 (Fed. Cir. 2004) (restricting application of $\S 1201$ where there was no underlying copyright claim).

35. 545 U.S. 913 (2005).

36. Id. at 934 . 
Corp. of America v. Universal City Studios, Inc. ${ }^{37}$ The Sony Court had protected a product manufacturer from secondary liability when the manufacturer had introduced a product "capable of substantial noninfringing uses." 38 Some analysts hoped that the Supreme Court would extend or narrow Sony to the question in Grokster, but even in Napster, the U.S. Court of Appeals for the Ninth Circuit had recognized that a peer-to-peer network was capable of both infringing and noninfringing uses. ${ }^{39}$

As the Court in Grokster explained, "[O]ne who distributes a device with the object of promoting its use to infringe copyright, as shown by clear expression or other affirmative steps taken to foster infringement, is liable for the resulting acts of infringement by third parties."40

Critics of DRM have been frustrated by the Grokster approach. "When the Supreme Court granted review ... technology developers hoped at minimum for a clearer statement of the applicable rule. Instead, the Court declined to resolve the disagreement, and compounded the uncertainty by articulating an alternative basis for contributory infringement liability based on intent to induce infringement." ${ }^{\prime 41}$ But this frustration assumes too much. Modern computers include standard CD-ripping software, digital video recording capabilities, cell phones with MP3 capabilities, iPods, and a dizzying array of technological innovations that have made the scope of the safe harbor a new ocean beyond the imagination of the Court that reviewed the video tape recorder in Sony.

While Grokster does not supplant either Sony or Napster, it harkens back to Gershwin Publishing Corp. v. Columbia Artists Management, Inc. ${ }^{42}$ to enforce the copyright axiom that "one who, with knowledge of the infringing activity, induces, causes or materially contributes to the infringing conduct of another, may be held liable as a 'contributory' infringer." ${ }^{43}$

For those concerned about a pernicious creep of copyright liability, one need only read Gershwin to put the scope of secondary liability in some context:

[I]n Screen Gems-Columbia Music, Inc. v. Mark Fi Records, Inc., 256 F. Supp. 399 (S.D.N.Y. 1966), the district court held that an advertising agency which placed non-infringing advertisements for the sale of infringing records, a radio station which broadcast such advertisements and a packaging agent which shipped the infringing records could each be held liable as a "contributory" infringer if it were shown to have had knowledge, or reason to know, of the infringing nature of the records. Their potential liability was predicated upon "the common law doctrine

37. 464 U.S. 417 (1984).

38. Id. at 442 .

39. A\&M Records, Inc. v. Napster, Inc., 239 F.3d 1004, 1029 (9th Cir. 2001).

40. Grokster, 545 U.S. at 936-37.

41. Cohen, supra note 11, at 9-10.

42. 443 F.2d 1159 (2d Cir. 1971).

43. Id. at 1162 (footnote omitted). 
that one who knowingly participates or furthers a tortious act is jointly and severally liable with the prime tortfeasor." 44

Under the decision in Grokster, one who traffics in black box software designed to decrypt access protection or download protection is an infringer under the current interpretation of vicarious liability. "[O]ne who distributes a device with the object of promoting its use to infringe copyright, as shown by clear expression or other affirmative steps taken to foster infringement, is liable for the resulting acts of infringement by third parties. $\$ 45$

Sony dealt with a claim of liability based solely on distributing a product with alternative lawful and unlawful uses, with knowledge that some users would follow the unlawful course. . . . MGM's evidence in this case most obviously addresses a different basis of liability for distributing a product open to alternative uses. Here, evidence of the distributors' words and deeds going beyond distribution as such shows a purpose to cause and profit from third-party acts of copyright infringement. If liability for inducing infringement is ultimately found, it will not be on the basis of presuming or imputing fault, but from inferring a patently illegal objective from statements and actions showing what that objective was. ${ }^{46}$

Section 1201 of the DMCA is consistent with Grokster and therefore supported by the Supreme Court's view of infringement. While the extent to which Sony has been modified by Grokster may be debatable, it does not diminish the safe harbor for those creating substantially noninfringing products, nor does it necessarily return to the broad secondary liability rules of Screen Gems-Columbia Music and Gershwin.

The DVD protection afforded by Corley has been extended to Macrovision's analog scrambling technology. ${ }^{47}$ In Macrovision, Sima was sued by Macrovision to enjoin the use of anticircumvention technologies for its software products "CopyThis!" and "GoDVD."48 Macrovision's technology adds a signal to DVDs that interferes with the video signal when recorded on analog VHS tapes but does not affect the viewing of the DVD. Sima's products disabled the Macrovision technology to allow analog copying of the motion picture on the DVD. ${ }^{49}$

The U.S. District Court for the Southern District of New York found that Sima was trafficking in devices that circumvent technological measures in violation of $\S 1201(\mathrm{a})(2){ }^{50}$ It found that the primary purpose of the de-

44. Id. (quoting Screen Gems-Columbia Music, Inc. v. Mark-Fi Records, Inc., 256 F. Supp. 399, 403 (S.D.N.Y. 1966)).

45. Grokster, 545 U.S. at 936-37.

46. Id. at 941 .

47. Macrovision v. Sima Prods. Corp., No. 05 Civ. 5587, 2006 U.S. Dist. LEXIS 22106 (S.D.N.Y. Apr. 20, 2006).

48. Id. at $* 2$.

49. Id. at *2-3.

50. Id. at *6 "Sima is in violation of each prong of $\S 1201(\mathrm{a})(2)$ of the DMCA, to Macrovision's detriment."). 
vices was to circumvent the Macrovision anti-copying technology and granted a preliminary injunction to bar the sale of the infringing products.

With both CSS and Macrovision adjudicated as protected by Section 1201 , the statute has been a clear legal victory for the motion picture industry. The court decisions assist the plaintiffs in enforcing the anti-copying technology by using cease-and-desist letters and preliminary injunctions to thwart manufacturers from profiting from the sale of these products.

In practice, such a legal victory has only marginal impact. ${ }^{51}$ The power of search engines has made even prohibitions against linking a rather pyrrhic victory. A search on Google reveals $1,010,000$ hits for a search using the term "DeCSS." 52 The only difficult thing in the search was finding a version of DeCSS that remains free. Prices for DVD "back up" programs and various rippers were typically low, but some were on sale for as much as $\$ 99.00 . .^{53}$

The legal decisions may enable plaintiffs to search out the domestic manufacturers of new software or hardware, but they hardly stem the tide against the thousands of websites where these types of products are renamed and re-released. International negotiators in 1996 could hardly have imagined an Internet-enabled world with millions of websites, peer-to-peer file sharing, and connection speeds that make the sharing of full-length movies commonplace. Against this technological backdrop, the positive legal impact is clear but unconvincing.

51. Professor Julie Cohen has effectively made this point:

DMCA-style laws do not physically or electronically prevent the spread of unprotected content or circumvention tools, and for that reason some critics consider them ineffective. For example, the DMCA did not prevent the development and widespread Internet distribution of DeCSS, the unauthorized program that decrypts prerecorded DVDs. Even after successful and widely-publicized litigation against several high-profile U.S. distributors of DeCSS, both the algorithm and movies decrypted with it remain widely available.

Cohen, supra note 11 , at 8.

52. Search conducted by author September 12, 2007 on Google.com. In addition to the 1,010,000 hits for "DeCSS," Google also estimated that "DeCSS Download" had 503,000 hits; "DeCSS Software" had 748,000 hits; and "DeCSS DVD" had 805,000 hits.

53. For example, a Google search resulted in a paid ad for www.soft411.com. The linked page posted eight products for sale ranging from $\$ 34.95$ for the Amazon DVD Shrinker to $\$ 99.95$ for CloneDVD by X Software. See Decss, http://www.soft411.com/software/decss.html (last visited May 4, 2008). Other sites do offer software for free. None of the programs were downloaded or their promises verified. 
C. Undermining Rights Management: Using the DMCA to Block Competition-Corporate Misuse of Anticircumvention for Anticompetitive Tricks

The success of the DMCA has not been without its own problems. If the Act is merely a "speedbump" intended to slow mass infringement, ${ }^{54}$ then it may have had little salutary value. The history of the statute focused on the entertainment and software industries' need to protect their primary revenue stream from theft. The statute was generally opposed by academics who feared the chilling effect that effective content control could have on the public. ${ }^{55}$ The debate simply did not extend to product manufacturers who have incidental software embedded in their products. ${ }^{56}$

As was feared when the DMCA was being debated, the problem is less that piracy is being attacked with additional tools than that the tools can be used to chill legitimate competition and academic inquiry. As I wrote when the statute was first being debated:

[The statute] will deter code breaking of computer games and add additional criminal penalties against hackers. This will also discourage game enthusiasts from sharing computer game passwords by making all the parties liable for copyright infringement. Taking the law only a small step further, this will also give each twelve-year-old legal redress against anyone reading his or her diary without permission, so long as it has a lock or a password. ${ }^{57}$

54. Timothy K. Armstrong, Digital Rights Management and the Process of Fair Use, 20 HARV. J.L. \& TECH. 49, 59 (2006).

55. Doris Estelle Long, "Electronic Voting Rights and the DMCA: Another Blast from the Digital Pirates or a Final Wake Up Call for Reform?", 23 J. MARSHALL J. COMPUTER \& INFO. L. 533, 549-50 (2005); Dan L. Burk \& Julie E. Cohen, Fair Use Infrastructure for Rights Management Systems, 15 HARV. J.L. \& TECH. 41, 54-70 (2001); Rebecca Tushnet, Copyright as a Model for Free Speech Law: What Copyright Has in Common with Anti-Pornography Laws, Campaign Finance Reform, and Telecommunications Regulation, 42 B.C. L. REV. 1, 1-2 (2000).

56. Product manufacturers had been intentionally removed from consideration in the contemporaneous discussions of the Uniform Computer Information Transactions Act (UCITA). Section 103 provides:

If a copy of a computer program is contained in and sold or leased as part of goods, this [Act] applies to the copy and the computer program only if: (A) the goods are a computer or computer peripheral; or (B) giving the buyer or lessee of the goods access to or use of the program is ordinarily a material purpose of transactions in goods of the type sold or leased.

UCITA, \& 103(b)(1) (2002), available at http://www.law.upenn.edu/bll/ulc/ucita/ucita200.htm. The model statute also excluded financial services, broadcast content, and other non-software agreements. While the UCITA evolved into a rather anti-consumer proposal, drafters were more prescient about the potential ramifications regarding overlap between industries than the WIPO treaty participants.

57. Jon M. Garon, Media \& Monopoly in the Information Age: Slowing the Convergence at the Marketplace of Ideas, 17 CARDOZO ARTS \& ENT. L.J. 491,537 (1999) (footnote 
When I wrote about the potentially overbroad use of anticircumvention technology, I continued to consider the protection of content, albeit of a very low-tech nature. I had not fully realized the extent to which companies would use the provisions to embed encryption into their products-or declare the software in their products to be encryption. This has led to a misuse of the statute that is potentially far more serious than academic concerns regarding encryption.

The leading cases involving anticircumvention technology, therefore, are not the cases brought by the entertainment and software companies against piratical activities, but are manufacturing disputes about product compatibility and after-market sales. The consumer products industries were given a jolt when Lexmark, ${ }^{58}$ the maker of computer printers, and Chamberlain, ${ }^{59}$ the manufacturer of electric garage door openers, each brought an action under the DMCA to stop competitors from using aspects of the software embedded in their products. Although ultimately the courts of appeal hearing these cases rejected the use of the DMCA as a tool to stop competitors from selling compatible products, the two decisions are simply too tentative and narrow to forestall many more attempts of a similar nature.

In Lexmark International, Inc. v. Static Control Components, Inc., the printer manufacturer attempted to use "Toner Loading Program," the toner cartridge software designed to check fill levels, and the "Printer Engine Program," which operated as the printer's operating software, to trigger the anticircumvention provisions of Section $1201 .^{60}$ The defendants sold toner cartridge computer chips to make the Lexmark toner cartridges eligible to be refilled. Initially, the district court granted a preliminary injunction

omitted). I have always had trepidations about the last statement in this article because I deleted the adjective "digital" from lock. The statute explains:

to "circumvent a technological measure" means to descramble a scrambled work, to decrypt an encrypted work, or otherwise to avoid, bypass, remove, deactivate, or impair a technological measure, without the authority of the copyright owner; and . . . a technological measure "effectively controls access to a work" if the measure, in the ordinary course of its operation, requires the application of information, or a process or a treatment, with the authority of the copyright owner, to gain access to the work.

17 U.S.C. $\S 1201$ (a)(3) (2000). While it seems that encryption is required, the phrase "otherwise to avoid, bypass, remove, deactivate, or impair" could include a simple mechanical lock. Id. Since turning a key is a process, I continue to reluctantly stand by my original statement in hope that a court will narrow this language before my own children begin keeping secret diaries. 2004).

58. Lexmark Int'l, Inc. v. Static Control Components, Inc., 387 F.3d 522 (6th Cir. 2004).

59. Chamberlain Group, Inc. v. Skylink Techs., Inc., 381 F.3d 1178 (Fed. Cir.

60. Lexmark, 387 F.3d at 529. 
against Static Control Components (SCC), the defendant. ${ }^{61}$ As the court explained,

[t]he authentication sequence that occurs between Lexmark's printers and the microchips contained on authorized Lexmark toner cartridges constitutes a "technological measure" that "controls access" to a copyrighted work. This authentication sequence requires the application of information and the application of a process to gain access to Lexmark's copyrighted Toner Loading Programs and Printer Engine Programs. ${ }^{62}$

At one level, the district court was entirely correct. The Toner Loading Program was necessary to run and operate the printer, and it was a technological measure controlling access to the printer. The Sixth Circuit pointed out that the two programs were not interrelated and that the Toner Loading Program was not needed to gain access to the Printer Engine Program; thus, it was not an effective control for anything. ${ }^{63}$

While it was true that Lexmark had not written the Toner Loading Program as an encryption program, nothing is to stop a manufacturer of one product from writing encryption into a second product. ${ }^{64}$ The Lexmark Court of Appeals was troubled by the paths its opinion left open for more enterprising plaintiffs:

Nowhere in its deliberations over the DMCA did Congress express an interest in creating liability for the circumvention of technological measures designed to prevent consumers from using consumer goods while leaving the copyrightable content of a work unprotected. In fact, Congress added the interoperability provision in part to ensure that the DMCA would not diminish the benefit to consumers of interoperable devices "in the consumer electronics environment." 65

The Sixth Circuit went a small step further, quoting the testimony of Professor Jane Ginsburg that "Section 1201(a) does not 'cover[] the circumvention of a technological measure that controls access to a work not protected under [the Copyright] title. And if we're talking about ball point pen cartridges, printer cartridges, garage doors and so forth, we're talking about works not protected under this title." ${ }^{\prime \prime 66}$

61. Lexmark Int'l, Inc. v. Static Control Components, Inc., 253 F. Supp. 2d 943, 974 (E.D. Ky. 2003).

62. Id. at 967-68.

63. Lexmark, 387 F.3d at 549.

64. See, e.g., Worlds of Wonder, Inc. v. Vector Intercont'l, Inc., 653 F. Supp. 135 (N.D. Ohio 1986) (copyright in Teddy Ruxpin talking bear extended to interaction with the cassettes played in the bear, so compatible cassettes were deemed infringing, and the performance of the animatronic bear was an unauthorized derivative work).

65. Lexmark, 387 F.3d at 549 (quoting 144 CONG. REC. E2136 (daily ed. Oct. 13, 1998) (statement of Rep. Bliley)).

66. Id. (quoting Anti-Circumvention Rulemaking Hearing, Copyright Office (2003) (testimony of Professor Jane Ginsburg), available at http://www.copyright.gov/1201/2003/hearings/transcript-may9.pdf). 
Writing in concurrence, Judge Merritt emphasized the need for courts to go beyond narrow, technical interpretations and eliminate the DMCA as a shield for manufacturers to delay legitimate competition:

\begin{abstract}
We should make clear that in the future companies like Lexmark cannot use the DMCA in conjunction with copyright law to create monopolies of manufactured goods for themselves just by tweaking the facts of this case .... The crucial point is that the DMCA forbids anyone from trafficking in any technology that "is primarily designed or produced for the purpose of circumventing a technological measure that effectively controls access to a [protected] work." 17 U.S.C. $\$ 1201(2)(A)$ (emphasis added). The key question is the "purpose" of the circumvention technology. ${ }^{67}$
\end{abstract}

The concurrence identified the central issue at stake in these anticompetitive "shield" cases. Courts must look to the copyright law as a body to determine whether the protected item is a copyrightable work or a commercial product with embedded software. While this approach will admittedly continue to require some line drawing, the line will be much more respectful of the consumer's interest than the current analysis permits.

The Federal Circuit has addressed these concerns both in Chamberlain and more recently in Storage Technology Corp. v. Custom Hardware Engineering \& Consulting, Inc. ${ }^{68}$ In Chamberlain, the court moved in the direction of the Lexmark concurrence by stating that Section 1201 "prohibits only forms of access that bear a reasonable relationship to the protections that the Copyright Act otherwise affords copyright owners." ${ }^{\prime 69}$ The court returned to the increasingly familiar concept that plaintiffs "must prove that the circumvention of the technological measure either 'infringes or facilitates infringing a right protected by the Copyright Act." "70 The Federal Circuit in Chamberlain and Storage Technology Corp. did not, however, embrace the notion that the work must be within the framework of copyright as a whole as suggested by Professor Ginsburg. ${ }^{71}$

If a new standard can be fashioned from these cases, then I suggest that it could be formulated rather simply as, " $A$ product, when taken as a whole, is substantially a work protected by copyright." Such items could be known as "DMCA Works" to reflect that the copyrighted elements enumerated by Section 1202 of the Copyright Act dominate the characteristic of the product. $^{72}$

67. Id. at 551-52 (Merritt, J., concurring).

68. 421 F.3d 1307 (Fed. Cir. 2005), reh'g denied, 431 F.3d 1374 (Fed. Cir. 2005).

69. Chamberlain Group, Inc. v. Skylink Techs., Inc., 381 F.3d 1178, 1202 (Fed. Cir. 2004). See also Storage Tech. Corp, 421 F.3d at 1318.

70. Storage Tech. Corp, 421 F.3d at 1318 (quoting Chamberlain, 381 F.3d at 1203).

71. Anti-Circumvention Rulemaking Hearing, supra note 66.

72. See 17 U.S.C. $\S 102(a)(2000)$.

Copyright protection subsists, in accordance with this title, in original works of authorship fixed in any tangible medium of expression, now known or later devel- 
Such a standard can be supported by the congressional testimony described above ${ }^{73}$ so that consumer electronics and non-content goods are outside the scope of the DMCA shield. It should be noted that most goods have copyrighted packaging, labeling, instructions, or other elements that are part of any consumer transaction, but these copyrightable elements do not transform the transaction into a consumer transaction for a copy of a copyrighted work. ${ }^{74}$ The classes of works described in Section 1201(1)(B) further support this interpretation. As the Copyright Office has explained:

The phrase "class of works" connotes that the shared, common attributes of the "class" relate to the nature of authorship in the "works." Thus, a "class of works" was intended to be a "narrow and focused subset of the broad categories of works of authorship ... identified in section 102."75 The starting point for a proposed exemption of a particular class of works must be the section 102 categories of authorship: literary works; musical works; dramatic works; pantomimes and choreographic works; pictorial, graphic and sculptural works; motion pictures and other audiovisual works; sound recordings; and architectural works. ${ }^{76}$

If the Commerce Committee report and the Librarian of Congress both limit works to those identified by Section 102, then the courts have ample justification to limit Section 1201 to the software, music, film, audiovisual, or literary works at issue in the WIPO treaties and the DMCA. The notion that the statute must be limited to copyrighted works and not merely consumer goods that have copyrighted elements can be supported by the legislative history as well as the common sense of the more intuitive courts.

Static Control provided yet another formulation in its petition to the Copyright Office to make consumer goods a class of works exempt from Section 1201. ${ }^{7}$ Static Control suggested that Section 1201(a)(1)(A) exclude

oped .... Works of authorship include the following categories: (1) literary works; (2) musical works, including any accompanying words; (3) dramatic works, including any accompanying music; (4) pantomimes and choreographic works; (5) pictorial, graphic, and sculptural works; (6) motion pictures and other audiovisual works; (7) sound recordings; and (8) architectural works.

Id.

73. Anti-Circumvention Rulemaking Hearing, supra note 66.

74. But see Quality King Distribs. v. L'anza Research Int'l, 523 U.S. 135 (1998) (use of label on hair products was the copyright interest used to attempt to stop parallel importation of labeled goods; because the labels were lawfully made under U.S. copyright law, the reimportation of the goods was protected by the first sale doctrine of $\S$ bl09(a)).

75. H.R. REP. No. 105-551, pt. 2, at 38 (1998), available at http://frwebgate.access.gpo.gov/cgibin/getdoc.cgi?dbname=105_cong_reports\&docid=f:hr55 1p2.105.pdf (Report of the House Committee on Commerce on the Digital Millennium Copyright Act of 1998).

76. Exemption to Prohibition on Circumvention of Copyright Protection Systems for Access Control Technologies, 70 Fed. Reg. 57526, 57529 (Oct. 3, 2005) (to be codified at 37 C.F.R. pt. 201) (quoting H.R. REP. No. 105-551, supra note 75).

77. Petition of Static Control Components, Inc., In the Matter of Exemption to Prohibition on Circumvention of Copyright Protection Systems for Access Control Technolo- 
"[c]omputer programs embedded in a machine or product and that control the operation of a machine or product connected thereto, but that do not otherwise control the performance, display, or reproduction of copyrighted works that have an independent economic significance[.]"78 Those works that do not have an independent economic significance are presumably the works that are embedded in goods where the consumer is acquiring the good and the software is not the purpose of the transaction. It is another way of saying that the product or good, taken as a whole, is not a protected work because the economic value of the product or good is outside the scope of copyright protection.

While I prefer the language that a work falls within the DMCA when it is a "work protected by the Copyright Act" or "substantially falls under the Copyright Act," rather than focusing on the independent economic significance of the good, the approach remains the same. The DMCA is an appropriate sword against piracy, black boxes, and anti-encryption software aimed at the music, film, media, gaming, and software industries. It should not be permitted to be wielded as a sword by one consumer product manufacturer against another.

There will undoubtedly continue to be line drawing involved to identify the boundary between DMCA works and consumer products. The retro joysticks that are sold preprogrammed with five 1980s video games may be the perfect example of a consumer good that is also a collection of audiovisual works protected by copyright. But even in these technologically revolutionary times, the hardware can generally be discerned from the software and the television separated from the programming it plays.

I have no doubt that juries will discern the difference between the shield of the DMCA and the misuse of the doctrine to protect snippets of computer code from being embedded in noncreative products. Makers of DVD players that decode the disc and enable the viewer to e-mail the content anywhere in the world will be enjoined. Juries will not grant relief to manufacturers of high-tech lawn mowers that suddenly need software to encrypt the "smart" spark plugs, oil filters, and disposable mulch bags that can only be supplied by the lawn mower manufacturer. But jury trials are expensive, and long litigation has a chilling impact on the marketplace. Preliminary injunctions have the potential for great economic harm. The language of the courts and Congress must streamline this process as quickly as possible.

Perhaps the most useful aspect is the clarity the DMCA brings to the ban on black box products, for this may be the one class of products that can be reached only through the statute. The author of such an anticircumven-

gies, No. RM 2002-4 (Copyright Office Jan. 23, 2003), available at http://www.copyright.gov/1201/2003/petitions/static.pdf.

78. Id. at 1 . 
tion device is directly and primarily liable under the various provisions of Section 1201. Whether such a device is simple to create, the independent use of Section 1201 has a place to discourage this type of piracy support.

For manufacturers of black box decrypters, there may be the ability to write anti-encryption code that does not begin with a particular encryption or utilize the software of a particular plaintiff. The result is that the defendant never copies any copyrighted work of the plaintiff, yet can create and traffic a program or device that others will use for widespread piracy. While the very creation may result in liability under Grokster because the creator and distributors have induced infringement, the anti-trafficking approach is much more explicit for retailers and others in the chain of distribution.

Similarly, all the wholesalers, retailers, and Internet vendors selling the black box device are responsible for the "trafficking" of the device. To the extent that the only effective method of impacting the manufacturer is to eliminate the profit for those benefiting from such devices, this liability is very helpful to the plaintiffs. Again, these resellers may be secondarily liable under Grokster and Sony, but the statute adds clarity.

Perhaps the more interesting question is whether the fight against piracy would be significantly different had Chapter 12 of the Copyright Act not been adopted. Given the modest number of lawsuits and the defendant's copyright infringement in every case, the likely answer is that piracy has not been changed by either the anticircumvention provisions or the antitrafficking provisions. Particularly since traffickers are generally going to be liable under Grokster, copyright law seems to have been perfectly capable of reaching all of the infringement impacted by Chapter 12. The statute adds clarity, but the impact remains modest at best.

\section{THE IWASTELAND}

If Chapter 12 has added only modest benefit, then perhaps the costs do outweigh the benefits. Professor Michael Geist reports that Bruce Lehman, former commissioner of the U.S. Patent and Trademark Office, suggested that the DMCA “"didn't work out very well." 79 Lehman is quoted as saying that "a new form of patronage will emerge with support coming from

79. Michael Geist, DMCA Architect Acknowledges Need for a New Approach, Mar. 23, 2007, http://www.michaelgeist.ca/content/view/1826/125/ ("The most interesting-and surprising-presentation came from Bruce Lehman, who now heads the International Intellectual Property Institute. Lehman explained the U.S. perspective in the early 1990s that led to the DMCA (i.e.[,] greater control though TPMs), yet when reflecting on the success of the DMCA acknowledged that 'our Clinton administration policies didn't work out very well' and 'our attempts at copyright control have not been successful' ...."). 
industries that require music (webcasters, satellite radio) and government funding." $" 80$

The DMCA does work effectively to ban black boxes and similar forms of infringement since "the DMCA explicitly states that a violation of the statute occurs when descrambling equipment circumvents a measure that 'effectively controls access' to a protected work. Measures based on encryption or scrambling effectively control access to copyrighted works." More importantly, the existence of DRM does not rely on the DMCA. DRM allows an owner of a copyright to manage access to the content by encrypting the content or locking the content behind passwords or other protections. If DRM was wholly effective at stopping break-ins, then the DMCA would be utterly superfluous since no potential pirate could ever gain access to the protected content. No encryption system is sufficiently robust, however, to avoid all break-ins, and audiovisual content needs to be compatible with standard players; therefore, the encryption is often quite easy to breach. ${ }^{82}$ "Copyright holders' deployment of DRM technologies sparked an ongoing 'arms race' of sorts, with each successive technological advance on one side being met by a response on the other." 83

The legal regime should work equally well regardless of whether the DMCA protects the encryption protocol or copyright protects the underlying work. Unauthorized copying would be actionable. While the measure of damages and criminal sanctions may vary, ${ }^{84}$ the essential liability would remain.

\section{A. Separating DRM from the DMCA}

The practical difference between a DRM regime and an encryptionfree regime is one of convenience and conscience. Audiovisual workssoftware, games, electronic books, DVDs, CDs, and similar media-are more convenient for the consumer without any DRM but are much more readily copied. For anyone who is ignorant or oblivious to the laws of copyright, the physical difficulty in copying large works becomes a signifi-

80. Id.

81. Comcast of Ill. X, LLC v. Hightech Elecs., Inc., No. 03 C 3231, 2004 U.S. Dist. LEXIS 14619 , at ${ }^{*} 17$ (N.D. Ill. July 28, 2004) (citing Universal City Studios, Inc. v. Reimerdes, 111 F. Supp. 2d 294 (S.D.N.Y. 2000)). See also CoxCom, Inc. v. Chaffee, No. 05-107S, 2006 U.S. Dist. LEXIS 86180 (D.R.I. Nov. 28, 2006); CSC Holdings, Inc. v. Greenleaf Electronics, Inc., No. 99 C 7249, 2000 U.S. Dist. LEXIS 7675 (N.D. Ill. June 1, 2000).

82. Armstrong, supra note 54. See Lee Kovarsky, A Technological Theory of the Arms Race, 81 IND. L.J. 917 (2006).

83. Armstrong, supra note 54, at 61 .

84. 17 U.S.C. $\$ 1204$ (a) (2000) (providing for a maximum $\$ 500,000$ fine and five years in prison for a first offense and twice those terms for subsequent offenses). 
cant barrier to copyright infringement. It would be far cheaper and easier to purchase an out-of-print paperback than to photocopy the same book. ${ }^{85}$ Conversely, before digital media, that which an individual could easily copy was generally considered fair use. The law tracked the practical expansion of technology, including photocopiers and videotape machines, to treat these personal activities as fair use. ${ }^{86}$

With the advent of digital technology, the correlation between convenience and fair use no longer holds true. Entire audiovisual works can be copied with relative ease. By clicking on a download button, a feature length film can be copied to one's computer. I suspect that illegal copies of most software programs, all commercially released CDs, and the majority of theatrically released feature films can be found on the Internet. Convenience no longer provides any guide to the public regarding the appropriateness of its conduct.

In publishing, an important practical consideration is the willingness of the audience to replace printed books with digital readers. The music experience was enhanced by computers and portable devices. Improvements in screen quality and better integration between televisions and computer-based media centers are bridging the divide for film and television. In contrast, online reading is still not as comfortable or convenient as paperbacks. Sony is currently offering its new book reader in a combination package of discounts that brings the retail price to $\$ 108.99$, including a library of 100 classic (e.g., public domain) books. ${ }^{87}$ Public domain books are also available for free through the Internet Archive, ${ }^{88}$ Project Gutenberg, ${ }^{89}$ and the Million Book Project. ${ }^{90}$ The cost barrier has been or will be breached this year. Amazon's Kindle has ignited strong interest in the technology. ${ }^{91}$ Whether the enhanced screen quality on Sony Reader, Apple's

85. At $\$ 0.05$ per copy, a 400 -page paperback would cost $\$ 10.00$ to photocopy, assuming each photocopied page showed two pages from the book.

86. Paul Goldstein, Copyright's Highway: From Gutenberg to the Celestial JUKEBOX 21-26 (rev. ed. 2003).

87. Sony, http://www.sony.com/reader (last visited May 4, 2008). The $\$ 349.00$ retail is discounted by a $\$ 50.00$ price reduction, $\$ 150.00$ Sony "new card" member discount, and $\$ 24.00$ in rewards points. The public domain titles cost $\$ 1.99$ to download. The discount ran August 4, 2007 through September 30, 2007.

88. Internet Archive, www.archive.org (last visited May 4, 2008).

89. Project Gutenberg, www.gutenberg.org (last visited May 4, 2008).

90. The Universal Digital Library, www.ulib.org (last visited May 4, 2008).

91. Eric Benderoff, In Hand, the Kindle Proves Appealing, CHI. TrIB., Dec. 10, 2007, at B5, available at http://www.chicagotribune.com/technology/columnists/chimon_techbuzz_1210dec10,0,848866.column. 
iPhone, or other current technologies has found the right mix remains to be seen. ${ }^{22}$

With every book or audiovisual product available online, DRM provides a reminder that the work should not be considered free for the taking. DRM provides a heightened warning label that when one copies the work without permission, one is breaking the law and stealing from the publisher. DRM's primary impact serves as a tug on the consumer's conscience that stealing a protected work is wrong. Ironically, the hue and cry surrounding DRM might be the evidence of its effectiveness. Given the ease with which DRM systems can be technologically circumvented, the legions of critics must be reacting to the moral implications of rights management rather than the impact DRM has on the availability of works.

If DRM cannot be sustained, then there exists a significant risk that the ability to challenge the conscience of consumers will erode as well. From that point forward, if DRM fails while the convenience of digital copying continues unabated, then consumer behavior is unlikely to improve. Instead, without DRM as a partial solution to illegal downloading, certain media forms such as publishing, video games, and motion pictures may be hurt in both finance and content.

Just as form follows function, content follows finance. Today the Internet exists much as television once did during its golden age, but then, as now, the fruits of artistic excellence were scattered across a wide landscape. FCC chairman Newton Minow's famous indictment still resonates when he chided that "[W]hen television is bad, nothing is worse. . . I I can assure you that you will observe a vast wasteland." 93 If the purveyors of tomorrow's content see the profits of their industries erode, they will invest less and take fewer risks on new artists. The artistic landscape will dry up, and we risk returning to the same vast wasteland.

92. See Lee Gomes, Anything Is Possible: Like Actually Enjoying a Good Digital Read, Wall St. J. ONLINE, Sept. 5, 2007, at Bl, http://online.wsj.com/article/SB1$18895184627717552 . \mathrm{html}$ ?mod=rss_Portals.

93. Newton N. Minow, Television and the Public Interest, Speech Before the National Association of Broadcasters (May 9, 1961), in The Vast Wasteland Revisited, 55 FED. COMM. L.J. 3, 398 (2003) (Symposium Issue), available at http://www.law.indiana.edu/fclj/pubs/v55/no3/Speech.pdf ("But when television is bad, nothing is worse. I invite you to sit down in front of your television set when your station goes on the air and stay there without a book, magazine, newspaper, profit-and-loss sheet, or rating book to distract you - and keep your eyes glued to that set until the station signs off. I can assure you that you will observe a vast wasteland. You will see a procession of game shows, violence, audience participation shows, formula comedies about totally unbelievable families, blood and thunder, mayhem, violence, sadism, murder, Western badmen, Western good men, private eyes, gangsters, more violence and cartoons. And, endlessly, commercials-many screaming, cajoling and offending. And most of all, boredom. True, you will see a few things you will enjoy. But they will be very, very few. And if you think I exaggerate, try it."). 
To convey this admittedly bleak picture, I would like to illustrate the artistic life of a person typical of my independent artist clients. In my casebook, ${ }^{94}$ I have a recurring artist named Bryce. ${ }^{95}$ Bryce is a gifted artist, developing works in every conceivable media the book covers. ${ }^{96}$ For Bryce the musician, DRM does more harm than good. Applied to only the miniscule portion of legally downloaded music, it ignores both CDs ripped to MP3 players and the music files illegally traded on peer-to-peer software. ${ }^{97}$ Like a stop sign applying to only one of every hundred cars driving through an intersection, DRM is an annoyance rather than a regulator. Steve Jobs has correctly recommended that the sound recording industry should abandon DRM for music because it has never taken hold. ${ }^{98}$

But Bryce is worried about other media. Bryce's science fiction stories have all been posted to the Usenet. In fact, like Harlan Ellison and other science fiction writers, Bryce can no longer be paid economically viable fees to write science fiction short stories. ${ }^{99}$ Piracy has eroded the genre. Massive novels like Harry Potter and Eragon remain in print, but short stories are moving from a professional to an amateur endeavor.

Noted author Jerry Pournelle described the situation in his blog:

I recent[ly] came across a web site that offered nearly every book Niven and I ever wrote, along with Asimov and Heinlein and many others, free, in .doc format. His defense was that he was making these works available to those who couldn't afford them. And of course he was taking advertisements. The only content that would attract people to his site was the copyrighted works of others. . . Without some kind of copyright protection no one will finance big movies, and even small movies are pretty expensive to make. Without some way to insure some return on time invested, authors won't write long and crafted books. Writing good books is hard work. It's less work to turn out pot boilers. It's less work to write copy for soup companies. ${ }^{100}$

94. Jon M. Garon, ENTERTAinment LaW \& Practice (2005).

95. Id. at 27 ("Meet Bryce. Bryce is a talented, up-and-coming artist-a hyphenate actor, writer, singer, director and producer-in other words, a fairly typical young talent. Throughout the course of the textbook, Bryce will engage in transactions involving the development of new ideas into film, music, television, theatre, and computer-game projects.").

96. Id.

97. See Jobs, supra note 1; Deana Sobel, A Bite out of Apple? iTunes, Interoperability, and France's Dadvsi Law, 22 BERKELEY TECH. L.J. 267, 281 (2007).

98. Jobs, supra note 1 ("Why would the big four music companies agree to let Apple and others distribute their music without using DRM systems to protect it? The simplest answer is because DRMs haven't worked, and may never work, to halt music piracy.").

99. GARON, supra note 94, at 531-32 (To quote Harlan Ellison: "Hundreds of writers' stories, entire books, and the work of a lifetime, everyone from Isaac Asimov to Roger Zelazny: Their work has been thrown onto the web by these smartass vandals who find it an imposition to have to pay for the goods.").

100. Jerry Pournelle, Computing at Chaos Manor: December 19, 2006, The User's Column, Column 317 , pt. 3 , available at http://www.chaosmanorreviews.com/open_archives/jep_column-317-c.php. 
Many in the science fiction and the short story worlds, however, are pleased by this explosion in access and distribution opportunity. Some of them are willing to accept the cost associated with piracy to build readership interest, or they philosophically dislike the economic model of the industry. Charlie Cross, for example, has written eloquently that DRM is far more damaging than piracy, and that piracy has had little impact on actual book sales. ${ }^{101}$

Moreover, the pressure Bryce has faced regarding the pay available may not be caused by piracy but by the ability to self-publish and distribute works on the Internet. The downward price pressure flows from the overabundance of available works, from both legitimate and pirated sources. As the costs for publication of e-books and e-magazines have dropped, the saturation of the market is no longer limited. Access to content is at an alltime high:

Hundreds (if not thousands) of stories are published every year in the science fiction and fantasy genres, in the professional magazines, in anthologies, as novella chapbooks, in semiprozines, and as previously unpublished stories in single-author collections, in addition to those "published" (we really need a new word for this!) electronically . . . and the brutal truth is that most of those hundreds of stories are going to vanish without a trace and never be heard from again. ${ }^{102}$

The technology and the proliferation of access has exploded the amount of content available, though it has not necessarily increased the amount of content actually read. I expect that the readership value for wellknown authors remains much higher than for unknown authors. Readers have little generic desire for content. Effective enforcement of DRM would separate out the economically valuable content of highly-recognized authors (who choose not to provide free distribution of their works) from the unknown or new authors in the same free marketplace. If the publishing world's economic structure is undermined by traffic in digitalized works from pirated copies, then both the industry and the audience will suffer. ${ }^{103}$ If instead, disintermediation and a surge in amateur, self-published, or start-up

101. The Charles Stross FAQ, http://www.antipope.org/charlie/fiction/faq.html (last visited May 4, 2008) ("I believe the ebook market is finally showing signs of maturation (with numerous cheap digital paper based readers due to arrive on the market in 2007-08), and I'm going to do my best to ensure that cheap and/or DRM-free ebook editions of my work are available wherever possible. (It is my opinion that DRM is immoral; it attempts to shake down our shared cultural heritage for an access fee, and imposes limitations on use that go far beyond the legal boundaries imposed by copyright law.)"). See also Charles Stross, Charlie's Diary: Why the Commercial Ebook Market Is Broken, http://www.antipope.org/charlie/blogstatic/2007/03/why_the_commercial_ebook_marke.html (last visited May 4, 2008).

102. Nebula Awards ShowCase 2006, at 1 (Gardner Dozois ed., 2006).

103. As with peer-to-peer file sharing, the relief was not sought against new artist programs. See A\&M Records, Inc. v. Napster, Inc., 239 F.3d 1004 (9th Cir. 2001). 
publications challenge the economic status quo, then the public will have spoken and the industry will have no choice but to respond.

What this suggests for the future of literature may be quite disconcerting. The number of works published and self-published is at an all-time high, while both reading and literacy are falling in the United States. ${ }^{104}$ Fewer than half of adults now read any form of literature. ${ }^{105}$ That reflects a ten percent or twenty-million person decline. ${ }^{106}$ College-age readership was down twenty percent, and the eighteen- to twenty-four age group was down twenty-eight percent. ${ }^{107}$

\section{B. Copyright as an Engine for Opportunity}

If copyright enforcement continues to erode, so will the risks publishers are willing to take. The impact is inevitable. "Authors may not actually get rich, but eliminating the opportunity, the profit motive, the chance to hit it big - that's going to eliminate good authors from even trying." 108

The risk in publishing is a vicious cycle:

[I]f publishers feel their profits are in jeopardy, they may pay lower advances (the initial payment to an author, often all they ever receive for those rights). Good writers, frustrated by their inability to make a living at this racket, will migrate to technical writing, advertising, journalism, or any other profession where they can use their talents to earn a living wage. So more and more of the "non-celebrity" books will be by authors willing to settle for any advance, no matter how little. And a general rule of thumb in any business is that the less you pay, the lessqualified are your job applicants. Think what this means for [your] future reading pleasure. $^{109}$

104. Publishing sales have remained steady at $\$ 10$ billion annually in net sales based on American Publishers Association data. See Book Business, 2006 Book Sales Remain Steady at $\$ 10$ Billion, Feb. 16, 2007, http://www.bookbusinessmag.com/story/story_singlepg.bsp?sid=47549\&var=story ("Overall trade sales in the United States saw a .02 percent year-over-year dip, or about $\$ 16.3$ million less in 2006 compared with 2005 sales, the report stated.").

105. National Endowment for the Arts News Room, Literary Reading in Dramatic Decline, According to National Endowment for the Arts Survey (July 8, 2004), http://www.nea.gov/news/news04/ReadingAtRisk.html.

106. National ENDOWMENT FOR THE ARTS, READING AT RISK: A SuRVEy of LITERARY READING IN AMERICA, RESEARCH DIV. REP. No. 46, at ix, available at http://www.nea.gov/news/news04/ReadingAtRisk.html.

107. Id. at xi.

108. Science Fiction and Fantasy Writers of America, Inc., FAQ, Frequently Asked Questions about Electronic Piracy (ePiracy), http://aburt.com/sfwa/epiracy-faq.html (last visited May 4, 2008) [hereinafter Burt, SFWA] ("The views presented here are those of Dr. Andrew Burt . .. and the many committee members who contributed-not those of SFWA's board of directors or of its membership, though many SFWAns share similar views, and their comments have gone into the creation of this page.").

109. Id. 
As predicted by the economic concerns of the Science Fiction Writers Association, potential writers such as Bryce are turning to other opportunities. Bryce does continue to write the occasional short story, earning either $\$ 10.00-\$ 25.00$ per story or $\$ 0.01-0.05$ per word, depending on the publication. ${ }^{110}$

Bryce turned to the stage, but professional theatre has been dying since before I was born, so what does that say. Theatrical patronage, however, has changed. Most plays now originate in the nonprofit regional theatres like the Guthrie, Steppenwolf, or Globe. Ticket prices have exceeded $\$ 300.00^{111}$ in New York and transformed theatre to an artificial, elite experience more like opera. An elite, self-referential theatrical world is fine until the audience evaporates.

At the professional theatre in St. Paul where I volunteer (not Bryce), 20,000 high school students get a chance to see Diary of Anne Frank, A Midsummer Night's Dream, and other plays, many based on traditional high school curricula. Often, this theatre trip is the only exposure these students have had to the theatre, and often they will attend only if a patron of the theatre can cover the cost for the production and the transportation. Many school districts have abandoned this educational exercise. Whither goest the Patron of the Arts for this generation? ${ }^{12}$

Discouraged by the opportunities in theatre, Bryce purchased a digital camera and opened accounts on YouTube, MySpace, Atomfilms, iFilm, and as many other sites as possible. A gifted writer and talented with the imagery of the medium, Bryce made both documentaries and films.

Bryce faced many challenges. The rough cut of a feature film included a character wearing a tee-shirt of R2D2. A review by the lawyer

110. See generally SpecFic World Market Newsletter \#29, available at http://www.specficworld.com/downloads.aspx (last visited May 4, 2008) (listing publishers and rates for science fiction and horror short stories).

111. See Campbell Robertson, Broadway's New Math: Top Dollars Equals Sales, N.Y. TIMES, May 8, 2006, at E1.

112. Dr. Burt of the Science Fiction Writers Association is more apoplectic than I am on the role of patronage. As with the school trip example, there will be many examples of beneficial patronage. Still, the long-term consequence of turning over the funding of content to a non-commercial and self-appointed elite or the government has dangerous implications and socially undesirable consequences:

Some pirates recommend returning to patronage-artists being sponsored by rich and powerful individuals or institutions. You want only fiction written that Bill Gates approves of? Only Republican or Democrat approved stories should be allowed? The founding fathers of the US were trying specifically to avoid this when they established the copyright protection system-it's what was used for a long time throughout Europe and felt to be stifling of new ideas. They wanted authors and inventors to be rewarded for their individual effort without control imposed on them by the rich and powerful. Stifling control by the rich and powerful is what the pirates are complaining about!

Burt, SFWA, supra note 108. 
explained that the copyrighted and trademarked image could not be used in the feature film without a license. But then the director of the "making of" documentary about Bryce's efforts in making a first feature film asked a question. "Bryce just wasted three days of shooting because of this Star Wars tee-shirt. Surely I can keep that scene in my documentary?"

The answer, of course, is less than clear. A review of cases suggests no litigation has occurred involving television or documentary films and the copyrights displayed on people's clothing. ${ }^{113}$ Arguably, documentary films are more newsworthy in nature and would receive a broader fair use privilege, ${ }^{114}$ but such an assertion is not specifically quantified. ${ }^{115}$ So the advice would allow the documentary to film the removal of the shirt from the fictional film.

If instead, the offending content were a ring tone or sudden moment of spontaneous song in the documentary, the pressure to seek a license would be much higher due to the more rigorous licensing practices for music. For sound recordings, there has become less and less fair use. Documentary filmmakers regularly face challenges for clearing incidental uses of music, often at very high costs. ${ }^{116}$ A six-second clip of a ringtone rendition of "Gonna Fly Now" from Rocky was licensed for $\$ 2,500$-down from the $\$ 10,000$ asking price noted in a documentary film about elementary school students. ${ }^{117}$

Licensing fee increases have been considered an economic response to consumer piracy. They allow the producers of content to recoup revenues at the choke point in the marketplace. A professional publisher or producer is much easier to identify and license or enjoin than the millions of consumers downloading without authorization. The shift in emphasis, unfortunately, harms the creation of new work, adding expense and discouraging creative cultural commentary.

Bullied by the challenges of licensing and the lack of markets for feature-length content, Bryce felt defeated. Most websites merely create op-

113. Search of Lexis Federal and State Cases database (conducted Aug. 31, 2007). Regarding set decorations (in fictional works), compare Ringgold v. Black Entertainment Television, Inc., 126 F.3d 70 (2d Cir. 1997), with Jackson v. Warner Brothers, Inc., 993 F. Supp. 585 (E.D. Mich. 1997).

114. See Monster Commc'ns, Inc. v. Turner Broad. Sys., Inc., 935 F. Supp. 490 (S.D.N.Y. 1996).

115. 17. U.S.C. $\S 107(2000)$ ("[T]he fair use of a copyrighted work . . for purposes such as criticism, comment, news reporting, teaching (including multiple copies for classroom use), scholarship, or research, is not an infringement of copyright."). See Harper \& Row, Publishers, Inc. v. Nation Enters., 471 U.S. 539, 552 (1985).

116. James Gibson, Risk Aversion and Rights Accretion in Intellectual Property Law, 116 YALE L.J. 882 (2007).

117. Nancy Ramsey, The Hidden Cost of Documentaries, N.Y. TimEs, Oct. 16, 2005, $\S 2$, at 13; Gibson, supra note 116 , at 893. 
portunities to post user content, ${ }^{118}$ but some even offered compensation for Bryce based on the hits to the posted films. ${ }^{119}$ But few viewers would watch an hour-long documentary or a ninety-minute film, even with a talented professional cast.

Bryce, however, was eventually successful.

Bryce is creative and clever. Bryce understands the economics of the Internet and the burgeoning new medium. As a result, Bryce's postings have become shorter and shorter. The clips are now under three minutes long. Usually they are just staged pratfalls. Bryce's original band is often featured lighting various props on fire and running away. They are sometimes funny and sometimes clever, and Bryce has started featuring consumer products in the clips. Bryce gets paid on the side for that. ${ }^{120}$

If Bryce can be successful, then perhaps the fear of cataclysm and aesthetic collapse is overstated:

Though today's movie industry may falter, we now have significant evidence that firms and industries are no longer necessary for the creation of extraordinarily complicated and otherwise expensive creative objects. Open source software ... provides the model for distributed production of complex creative objects. . . . There are, by now, a sufficient number of examples of this type of open source creativity, in areas including software, newspapers, and commentary, for us to conclude that this type of organization can supplant the firm in the production of complex creative objects. ${ }^{121}$

Of course, this observation is correct, but at least thus far the exceptional explosion of talent and attention to YouTube.com and other film sites has resulted in a massive increase in the number of clips created, rather than in any collaborative, socially-networked motion pictures. Certainly there are ways to create a "story bible" in which various filmmakers each take aspects of the story to tell, which is then publicly distributed. Set against the common backdrop of an interesting plot and premise, such an experiment could yield wonderful results. ${ }^{122}$ But this would not replace traditional filmmaking.

118. See, for example, Spike, http://www.spike.com/ (last visited May 4, 2008); AtomFilms, atomfilms.com (last visited May 4, 2008); YouTube, youtube.com (last visited May 4, 2008).

119. E.g., Metacafe, What is Producer Rewards?, http://www.metacafe.com/producer_rewards/) (last visited May 4, 2008).

120. Bryce started working on a video game, but the source code was posted to the net while the game was in beta. The game is quite popular, I'm told, but no publisher will distribute what it views as an open source product. Of course, it was not open source when Bryce designed it, but the software has been mirrored on too many sites.

121. Dan Hunter \& F. Gregory Lastowka, Amateur-to-Amateur, 46 WM. \& MARY L. REV. 951, 1016-17 (2004) (footnotes omitted).

122. To elaborate further: the project would be based on a particular story such as the legend of King Arthur. To create a socially networked media experience, an open invitation to filmmakers would encourage each to tell the story from the perspective of a character 
While it is unfair to suggest that disintermediated filmmaking will never develop simply because it has not developed yet, the highly sophisticated and heavily interdisciplinary nature of the craft suggests that it will not readily lend itself to the iterative and collaborative process of software development. Both filmmaking and software development may be complex, but their methodologies bear little in common.

Bryce, of course, remains hopeful. One possibility is that the short works are allowing Bryce to learn the craft of filmmaking and encapsulate stories into the compressed time frame of the Internet Webisode or clip. As a medium, the short clip does create an opportunity for practice, but critics are yet to embrace it even for the commercial hits: ${ }^{123}$

The Webisode is to network television what an M\&M's Mini is to candy: it can please, but can't satisfy. . . . Someday soon, all television will be available on cell phones, iPods and laptops, and a better balance between content and commercials will presumably be found. Right now, network Web sites are a piercing shriek of visual noise. ${ }^{124}$

None of this activity, however, has earned Bryce enough money to pay even the legal fees associated with the production costs.

\section{Patronage Revisited-Is Everything Old NeW Again?}

As indicated earlier, the worst-case scenario faced by Bryce represents an apocryphal world where the failure of DRM equates with the failure of copyright. Copyright will not utterly fail. Instead, laws will continue to protect against commercial exploitation by identifiable publishers because the source of the infringement can be found. The benefits of statutory damages and attorneys' fees for registered works will continue to provide a sufficient economic reward to bring copyright claims against any party with the means to satisfy the judgment.

The failure of DRM creates an inherent assumption that the law is insufficient to stop "noncommercial" piracy, peer-to-peer systems, overseas websites, and other methods of distributing content in a manner that makes cease-and-desist actions a shell game. In consequence, the rights holders will continue to emphasize license fees where commercial publishers and distributors are required to pay. Fees for ringtones, musical licenses for films and documentaries, and other non-consumer transactions will continue

known in the legend, including all the knights, those vanquished, Merlin and all those with whom he interacted during his lifetime living backwards through time, etc. The immersive story could grow indefinitely, like fan fiction relating to a literary character.

123. Alessandra Stanley, NBC's Web-Only Episodes Offer 'The Office,' a Little at a Time, N.Y. TimEs, July 18, 2006, at E6.

124. Id. 
to play an increasingly pivotal role in the economics of the entertainment industries.

\section{A. Revisiting the Economic Underpinnings of Entertainment}

The question remains whether the available revenue streams will be sufficient to sustain the consumer-market model for content, whether advertising is preferential, or whether a return to a patronage is likely. ${ }^{125}$ Not all the entertainment fields use the same model, so a more accurate description of the future will include a shift in emphasis among the economic models rather than any cataclysmic collapse of consumer sales. Assuming media content will remain a professional pursuit in which the artists and authors are economically rewarded, there are only a few sources for the revenue.

The first U.S. model for content financing is direct consumer purchasing. At one extreme, a market may be entirely consumer driven, so that all revenue is derived through ticket purchases and product purchases. Arguably, this model should be most responsive to the public market because it economically rewards only that for which the public is willing to pay.

The second financing model is advertising-based funding, a variation on consumer payment. Through advertising-supported consumer consumption, advertisers pay for access to the audience as it watches, listens, or participates in the medium. The consumer does not pay directly for the content, but independent measures of consumer behavior help the industry set the value of the advertising. The public ultimately pays for the cost of content as the cost of advertising is added to the charges for products and services. In the case of broadcast radio and over-the-air television, all revenue is advertising-derived, and the audience pays nothing for the content it receives.

Magazine publishers use a combination of consumer purchasing and paid advertising to earn their income, reducing but not eliminating the direct cost for the consumer. Cable television and satellite radio are similar, but not the same as the magazine medium. In the case of the cable and satellite broadcasters, the consumer is paying for access to a wide range of content rather than paying for a particular channel or show. The payment shows the willingness of the consumer to receive the medium but not any particular message.

A third but minor source of existing funding comes from federal and state governments. ${ }^{126}$ This source is much more significant in other countries, where the state has official television networks, radio stations, or

125. See generally Note, Exploitative Publishers, Untrustworthy Systems, and the Dream of a Digital Revolution for Artists, 114 HARV. L. REV. 2438, 2440-41 (2001).

126. See Jennifer Weatherup, Agencies and the Arts: The Dilemma of Subsidizing Expression, 24 J. NAT'L AsS'N ADMIN. L. JuDGES 271, 272-73 (2004). 
newspapers. ${ }^{127}$ Nonetheless, the United States does have the Corporation for Public Broadcasting, a nonprofit entity created by Congress. ${ }^{128}$ In addition, grants from the National Endowment for the Arts, the National Endowment for the Humanities, and state-funded agencies comprise part of the funding landscape for arts, entertainment, and culture in the United States.

While there is no direct conflict with the free speech rights embodied in the Constitution, ${ }^{129}$ governmental funding of content necessarily puts the government in the role of selecting or preferring editorial content. ${ }^{130}$ For "although the First Amendment certainly has application in the subsidy context, we note that the $[\mathrm{g}]$ ]overnment may allocate competitive funding according to criteria that would be impermissible were direct regulation of speech or a criminal penalty at stake." 131 Despite this assertion that governmental funding gives Congress wide latitude, there has at least been recognition by the U.S. Supreme Court that such latitude should come with some respect for the ideals in the First Amendment:

\begin{abstract}
When Congress first decided to provide financial support for the expansion and development of noncommercial educational stations, all concerned agreed that this step posed some risk that these traditionally independent stations might be pressured into becoming forums devoted solely to programming and views that were acceptable to the Federal Government. That Congress was alert to these dangers cannot be doubted. It sought through the Public Broadcasting Act to fashion a system that would provide local stations with sufficient funds to foster their growth and development while preserving their tradition of autonomy and communityorientation. A cardinal objective of the Act was the establishment of a private corporation that would "facilitate the development of educational radio and television broadcasting and ... a afford maximum protection to such broadcasting from extraneous interference and control."132
\end{abstract}

127. See Anthony E. Varona, Changing Channels and Bridging Divides: The Failure and Redemption of American Broadcast Television Regulation, 6 MINN. J. L. SCI. \& TECH. 1, 9 (2004); Thomas M. Murray, The U.S.-French Dispute Over GATT Treatment of Audiovisual Products and the Limits of Public Choice Theory: How an Efficient Market Solution was “Rent-Seeking”, 21 MD. J. INT'L L. \& TRADE 203, 207 (1997).

128. 47 U.S.C. $\S 396($ b) $(2000)$.

129. Nat'l Endowment for Arts v. Finley, 524 U.S. 569 (1998) (upholding contentbased requirement that decency and respect be considered in NEA grants).

130. See, e.g., United States v. Am. Library Ass'n, 539 U.S. 194 (2003) (allowing filtering software requirements in public libraries); FCC v. League of Women Voters, 468 U.S. 364 (1984) (barring prohibition on political editorials); Regan v. Taxation with Representation of Washington, 461 U.S. 540 (1983) (upholding prohibition on lobbying activities by tax-exempt entities).

131. Finley, 524 U.S. at 587-88.

132. League of Women Voters, 468 U.S. at 386-87 (quoting 47 U.S.C. $\S 396(\mathrm{a})(6)$ (1976)). 
In recent years, however, Congress has not sought to immunize itself from the temptation to use appropriations to affect the public discourse. ${ }^{133}$ These tendencies tend to rise and fall with the controversy of the day, but over time, the inevitable impact of funding is to shift the focus of content toward the interest of the funding source. Even if laws such as those described for the Corporation of Public Broadcasting are in place, there will be an inevitable interrelationship between content and the funding source.

Inevitably, if governmental funding-or even governmental control over rates and disbursements-becomes the dominant force in the remuneration system, it will affect the content. ${ }^{134}$ A system of direct government funding for media will not be secure from government control of the content produced thereunder.

The fourth source of funding is from private patronage. Charitable tax-exempt organizations collect private donations for visual art, theatre, opera, libraries, motion pictures, public broadcasting, and publishing endeavors of various kinds. Private patronage already pervades the noncommercial side of the entertainment industry. Because it is charitable or nonprofit under our tax codes, it is lumped together with religious and educational beneficence. ${ }^{135}$ Private patronage has always been part of the art scene, arguably the engine behind the avant garde and an important part of innovation in arts and culture. The donors are often the great families in each community, lending both their names and their resources to the cultural vibrancy of their communities.

Today, many of these same families participate on the commercial side as well, dabbling in film funding because they have the financial capacity to take losses that come far more often than the gains. Assuming that the wealthy patrons reflect a reasonable cross-section of the public, then the generosity of these patrons may result in content not wholly different than the content created by commercial reinforcement. Of course, this assumption may be inaccurate. Potentially, the incentives to fund media will be directed to more "important" or socially desirable works, so the content

133. See Richard J. Peltz, Pieces of Pico: Saving Intellectual Freedom in the Public School Library, 2005 BYU EDUC. \& L.J. 103 (2005); Arthur N. Eisenberg, The Brooklyn Museum Controversy and the Issue of Government-Funded Expression, 66 BROOK. L. REV. 275 (2000); Lee C. Bollinger, Public Institutions of Culture and the First Amendment: The New Frontier, 63 U. CIN. L. REV. 1103 (1995).

134. See Weatherup, supra note 126, at 303-04. See also Brenda L. Tofte, Note, "Baby, It's Cold Outside:" The Chilling Effect of the Decency Clause on the Arts in the Aftermath of National Endowment for the Arts v. Finley, 22 HAMLINE L. REV. 303, 314 (1998).

135. See 26 U.S.C. $\S 501(c)(3)$ (2000) ("Corporations ... organized and operated exclusively for religious, charitable, scientific, testing for public safety, literary, or educational purposes ...."). 
funded will be more erudite than the content funded with advertising or direct consumer purchases.

The Harlequin Romance is less likely to receive donor funding than the literary novel. Of course, public television trends suggest that shows such as Great Performances have been supplanted with reunion specials of folk and pop stars from the previous generation. If this is the real trend, then the socially desirable and funded content will simply skew on the older side, following the demographics of wealth.

Finally, a fifth category of financing has emerged that builds upon the intersection of advertising and patronage. Under the "distributor funding" model, consumer electronics companies and telecommunications companies rely on the desirability of content to fuel the sale of products and services. Companies like Apple, Intel, Microsoft, Dell, or HP; integrated companies like Sony and TimeWarner; and telecommunications backbone companies like Comcast and AT\&T remain hungry for content.

Distributor funding focuses exclusively on popularity without regard to quality. These companies have no structural need to care about either the quality or the message of the shows promoting their advertisements; they only need the content to flow through their pipelines and onto the devices they sell. Just as Gillette once famously discounted razors to sell razor blades, these companies will give away content so long as we buy the machines and subscribe to the delivery services. Perhaps popularity is sufficient and society need not concern itself with other measures of quality, but I can think of few works today that compare favorably with the quality of television in 1961 when Newton Minow called television the great wasteland. ${ }^{136}$

Distributor funding will emphasize the quantity of content available over the quality. Time spent using the distributor's service to find artistic needles in the haystack will not matter, because so long as the audience is engaged, the distributor benefits. YouTube is an example of a business that supports both Google (its owner) and the internet service providers that promote audience interaction with the service. Some of the content is funny, some is fascinating, and the medium will only undoubtedly mature over time. But the economic model relies on participation rather than quality. This may not be significantly different from the advertising model. ${ }^{137}$ While

136. Minow, supra note 93.

137. A small but potentially significant distinction between advertising and distributor supported content is the association made with the underlying material. An advertiser generally tries to associate itself with positive aspects of the content in which its commercials are aired. A distributor, in contrast, is responsible for all the content available on its network, so it is unable to claim any benefit for higher quality content. So a cable company has even less incentive than an advertiser to be concerned about the nature of the content generating the revenue from its customers. 
there is some brand development for premium brands that wish to be associated with more refined content (particularly in magazine advertising), most radio and television advertising focuses on market size. As such, the distribution funding model is merely an extension of the advertising model.

In television, HBO represents a consumer-payer model, while broadcast television represents the advertising model. Most cable channels reflect the mixed model of consumer payment, distributor funding, and advertising. The mix of economics varies from channel to channel.

\section{B. Balancing the Models for Entertainment Funding}

In legitimate theatre, including Broadway, off-Broadway, and other professional theatre, the models are highly mixed. A new musical may be developed at a nonprofit, regional theatre where the theatre's budget is approximately fifty percent ticket sales and fifty percent charitable donations. ${ }^{138}$ That same musical could open in a for-profit theatre on Broadway. A non-musical play could do the same, but it is far less likely that the play would be economically viable on Broadway. Other plays and musicals, however, which might be produced in nonprofit theatres, would never be commercially viable in New York's for-profit marketplace. Moreover, most markets have no for-profit theatre at all. Of those that do, the for-profit entities do not produce original plays or musicals. Instead, they book touring companies that play for a few days or a week in that location before moving on to the next city. Disney has further blurred the distinction as the only theatrical producer that integrates musical theatre with film, television, and other entertainment products.

Live theatre continues to flourish in the United States as a result of the mixture of donor-supported patronage augmented by Broadway's commercial producers. More realistically, even Broadway should be described as a patronage system. Although the investors do not receive a charitable deduction for their investments, the industry term of "angels" reflects their altruistic or personal motivation, rather than realistic commercial goals. The angels of Broadway are more accurately depicted as the modern Medicis, investing in the art as a quasi-commercial exercise in culture and influence. Through their beneficence, they keep legitimate theatre away from the elitist isolation of opera even as the non-commercial donors veer it away from the mere spectacle of the modern circus.

138. Zannie Giraud Voss \& GlenN B. Voss, Theatre Facts 2006, A RePORT on Practices and Performance In the American Not-For-Profit Theatre Based on the ANNUAL TCG FISCAL SURVEY 2, 4 fig.2 (2006), available at http://www.tcg.org/tools/facts/index.cfm (reporting an average of $52 \%$ earned income and $48 \%$ contributions for its 1,893 reporting theatres). 
Since the public has become quite familiar with the patronage model, we assume it works well. The art form balances "popular" comedies with "important" dramas. Theatres add perennial Christmas favorites or popular musicals to infuse the annual production budgets. Through this balance, the theatrical season responds in a generally acceptable manner to both audience and patron expectations. So despite concerns that we abandon consumer payment in content for an entirely patron- or consumer-electronicsfunded system, the reality is that most media have a mix of consumer payment, advertising, patronage, government, and-increasinglyunderwriting by consumer electronics/telecommunications distributors. A change in emphasis will result in a change in the nature of the content being produced, but the benefits or detriments of such a chance are unclear and likely unknowable.

Does this mean that my concern for Bryce is unfounded? Unfortunately not. The opportunity for Bryce to flourish in the new landscape continues, but the wasteland will spread if the funding sources do not value quality as one of the parameters. Perhaps the current advertising model has already pushed society down that slippery slope, but the speed of descent will only accelerate if telecommunications companies and consumer electronics concerns continue to tout quantity over quality, and if the true moderating control of direct consumer spending is eliminated.

A more elitist view would suggest that the emphasis should shift to patronage and the nonprofit donor as the preferred source of funding. But this, too, distorts the content. Perhaps donor funding enriches it, but nonetheless such funding changes the content available to the public and, by consequence, which authors and artists we will support.

So long as audience members pay for content, they play a critical role. They insist that the dollars they spend go to content worth reading and viewing. Even with television, there is a difference between television ratings and purchases of videotapes/DVDs of previously broadcast content. I believe that this reflects the qualitative difference between what we are willing to occasionally watch and the content in which we will invest, subscribe, and keep. The regional theatre model of a balance between audience ticket sales and donor funding keeps the demands of the audience and the donors in a healthy tension, placing a premium on content that can meet these twin goals.

\section{Expropriating Patrons-Ownership by EULA}

Bryce faced one additional hurdle. Attempting to be creative, Bryce created a minstrel character for World of Warcraft, a massive multiplayer 
online game. ${ }^{139}$ Unfortunately, the game was not well-suited to Bryce's musical musings. A friend tried to help Bryce by copying the character to an "open access" version of the game to allow Bryce to move the character to another game. Bryce's friend tried to "open" the game so as to allow him to edit Bryce's character. In doing so, he triggered yet another of the problems inherent with the DMCA - the intersection between the statute and licensing agreement associated with the protected software.

End user license agreements (EULA) and terms of use agreements (TOU) set the terms and conditions for access to the content of digital media. These license agreements can go well beyond the safeguards built into the DMCA to reduce the interoperability of software and otherwise change the policy balance woven throughout the Copyright Act by often requiring that all user-created content be the intellectual property of the game publisher. ${ }^{140}$

In Davidson \& Associates v. Jung, ${ }^{141}$ the Eighth Circuit reviewed the role of an EULA in the context of the DMCA. The agreement in question was carefully written and executed. The language in the shrinkwrap and clickwrap agreement was as follows:

YOU SHOULD CAREFULLY READ THE FOLLOWING END USER LICENSE AGREEMENT BEFORE INSTALLING THIS SOFTWARE PROGRAM. BY INSTALLING, COPYING, OR OTHER WISE USING THE SOFTWARE PROGRAM YOU AGREE TO BE BOUND BY THE TERMS OF THIS AGREEMENT. IF YOU DO NOT AGREE TO THE TERMS OF THIS AGREEMENT, PROMPTLY RETURN THE UNUSED SOFTWARE PROGRAM TO THE PLACE OF PURCHASE OR CONTACT BLIZZARD ENTERTAINMENT CUSTOMER SERVICE . . . FOR A FULL REFUND OF THE PURCHASE PRICE WITHIN THIRTY DAYS OF THE ORIGINAL PURCHASE.

This software program (the "Program"), any printed materials, any on-line or electronic documentation, and any and all copies and derivative works of such software program and materials are the copyrighted work of Blizzard Entertainment. . . . Subject to that Grant of Licence [sic] hereinabove, you may not, in whole or in part, copy, photocopy, reproduce, translate, reverse engineer, derive source code, modify, disassemble, decompile, create derivative works based on the Program, or remove any proprietary notices or labels on the Program without the prior consent, in writing, of Blizzard. ${ }^{142}$

139. World of Warcraft, http://www.worldofwarcraft.com/index.xml (last visited May 4, 2008).

140. See Andrew Jankowich, EULAW: The Complex Web of Corporate Rule-Making in Virtual Worlds, 8 TUL. J. TECH. \& INTELL. ProP. 1, 37 (2006); Robert L. Oakley, Fairness in Electronic Contracting: Minimum Standards for Non-Negotiated Contracts, 42 Hous. L. REV. 1041, 1049 (2005).

141. 422 F.3d 630 (8th Cir. 2005).

142. Id. at 635 . 
The language of the license effectively prohibited a wide variety of conduct for the material, most of which is already prohibited by copyright or trademark law. The agreement cleverly and effectively provided the end user with a method of unwinding the transaction in the event that the terms were not anticipated prior to installation. The inclusion of the language in the installation and the packaging eliminated virtually all possible claims that the end purchaser acquired the software free of the agreement. As a result, the EULA represents thoughtful and careful advocacy on behalf of Blizzard Entertainment, ${ }^{143}$ the gaming company that used this language as part of its launch of Battle.net.

Blizzard was also conscientious regarding the installation and encryption:

With the exception of "Diablo," each authorized version of a Blizzard game comes with a "CD Key." A CD Key is a unique sequence of alphanumeric characters printed on a sticker attached to the case in which the CD-ROM was packaged. To $\log$ on to Battle.net and access Battle.net mode, the game initiates an authentication sequence or "secret handshake" between the game and the Battle.net server. In order to play the Blizzard game contained on a CD-ROM, a user must first install the game onto a computer and agree to the terms of the End User Licence [sic] Agreement ("EULA") and Terms of Use ("TOU"). ${ }^{144}$

Combining an effective control over access to the content with a welldrafted agreement will create the type of consumer obligation sought by software licensors. Blizzard followed these steps well and serves as an effective model for drafting and product distribution.

The facts in Davidson are not sympathetic to the defendants. The defendants decrypted the software protecting the games at the Battle.net site, reverse-engineered games and posted an open source version of the Battle.net site, created and distributed anticircumvention software, and created a home for pirated Blizzard games because they had removed the need for authentication. ${ }^{145}$ Under the Grokster standard, "one who distributes a device with the object of promoting its use to infringe copyright, as shown by clear expression or other affirmative steps taken to foster infringement, is liable for the resulting acts of infringement by third parties." 146 Through the many steps taken by the defendants in Davidson, they were secondarily liable for inducement when they undertook to strip the protections from the Blizzard games and create the online location for players to use their illegal copies of the games.

143. Blizzard Entertainment is a subsidiary of Vivendi Universal Games, Inc.

144. Jung, 422 F.3d at 634 (footnotes omitted).

145. Id. at 636-37.

146. Metro-Goldwyn-Mayer Studios Inc. v. Grokster, Ltd., 545 U.S. 913, 936-37 (2005). 
This, however, was not the question before the Eighth Circuit in Davidson because liability had already been established. The court quickly found that the defendants had violated Section 1201. The legal question remaining on appeal was the extent to which the DMCA provisions provided a safe harbor for the defendants.

Despite the earlier discussion of the EOLA and TOU, the Eighth Circuit did not directly answer the question regarding the reverse-engineering limitation. It focused on the narrowness of the statutory exception in Section 1201(f) that circumvention is allowed "for the sole purpose' of trying to achieve 'interoperability' of computer programs through reverse engineering." 147 The court identified a four-prong test for when to use the exception:

To successfully prove the interoperability defense under $\$ 1201(f)$, Appellants must show: (1) they lawfully obtained the right to use a copy of a computer program; (2) the information gathered as a result of the reverse engineering was not previously readily available to the person engaging in the circumvention; (3) the sole purpose of the reverse engineering was to identify and analyze those elements of the program that were necessary to achieve interoperability of an independently created computer program with other programs; and (4) the alleged circumvention did not constitute infringement. ${ }^{148}$

Although the Eighth Circuit did not apply this test to the interoperability discussion, earlier in the opinion it stated that

"[p]rivate parties are free to contractually forego the limited ability to reverse engineer a software product under the exemptions of the Copyright Act[,]" and "a state can permit parties to contract away a fair use defense or to agree not to engage in uses of copyrighted material that are permitted by the copyright law if the contract is freely negotiated."149

Had the court explained that the breach of the EULA or TOU rendered this not a lawful use of the program, then it would be clear that reverseengineering for interoperability may be waived. Instead, the Eighth Circuit focused on the "sole purpose" for reverse-engineering in the third prong of the defense. The defendants failed to establish this prong and thus lost on their Section 1201(f) defense. ${ }^{150}$

Unfortunately, there is a strong inference in Davidson that similar EULA or TOU language can eliminate Section 1201 (f) even if the fourprong test is otherwise followed. Such an inference is misguided because the approach will undermine the statutory balancing of public interests.

147. Davidson \& Assocs. v. Jung, 422 F.3d 630, 641 (8th Cir. 2006) (quoting 17 U.S.C. $\S 1201(\mathrm{f})$ ).

148. Id. at 641-42.

149. Id. at 639 (citation omitted) (quoting Bowers v. Baystate Techs, Inc., 320 F.3d 1317, 1325-26, 1336 (Fed. Cir. 2003)).

150. Id. 
At worst, the violation of the EULA or TOU is a breach of contract. It should not rise to the level of an illegal acquisition of the software. ${ }^{151}$ If the breach does not make the acquisition of the software illegal, then a legitimate competitor can reverse-engineer solely for the purpose of interoperability without infringing the other party's copyright. ${ }^{152}$ Congress intended the prior decisions, such as Sega v. Accolade, to continue to allow companies to reverse-engineer their rivals and to utilize fair use to allow sufficient copying to achieve interoperability. ${ }^{153}$

The tension within the marketplace is that media companies often find themselves on both sides of interoperability. The dominant author of one software platform or game may wish to discourage interoperability to maintain its monopoly. In another product, however, that same company may need to create a software product or module that works with a competitor's product to achieve interoperability with its software.

The hearings on the DMCA strongly support the continued viability of Sega and reverse-engineering. The Senate Report stated, "The objective is to ensure that the effect of current case law interpreting the Copyright Act is not changed by enactment of this legislation for certain acts of identification and analysis done in respect of computer programs."154

Ultimately, the consumer is much better served with broad legal protection for interoperability, which enhances ease of use and compatibility for the end user. The congressional intent of Section 1201(f) reflects this positive view of interoperability.

The entertainment and software industries are internally divided on the policy, however. Well-established companies generally benefit from the status quo, so they are more likely to seek bars to interoperability while smaller or independent companies stand in much greater need of protection through interoperability. The policy pits software and media companies against one another. Because of the entwined ownership of software and media companies, these policies may even pit divisions of the same conglomerate against each other.

To achieve the goals of Section 1201(f), Congress may need to specifically void any private agreements that bar reverse-engineering for the purposes of interoperability. Such a proposal would inevitably invite re-

151. Careful drafting can make this distinction less clear. For example, an EULA provision states that "Licensee's failure to comply with this Agreement results in the immediate termination of this license to use the [Software]. Any use of the Software following such termination is a violation of Licensor's copyright in the Software." While it may not be good public policy to allow licensors to criminalize contract breaches with clever drafting, the difficulty remains.

152. See Sega Enters. Ltd. v. Accolade, Inc., 977 F.2d 1510, 1525 (9th Cir. 1992); Atari Games Corp. v. Nintendo of Am., Inc., 975 F.2d 832 (Fed. Cir. 1992).

153. S. REP. No. 105-190, at 32 (1998). See Accolade, Inc., 977 F.2d at 1527-28.

154. S. REP. NO. 105-190, at 32 (1998). 
quests for similar protection for fair use, other non-infringing reverseengineering purposes, and other aspects of the EULA and TOU agreements. Since many of these would be considered controversial by the industry representatives, such a proposal will be difficult to enact. A simpler approach would be for courts to recognize that breaches of an EULA and TOU are not crimes or torts. They are merely breaches of contract. As such, courts should not bar parties from continuing to seek interoperability of software, a goal consistent with the congressional intent of current copyright policy. ${ }^{155}$ This would not provide protection to the defendants in Davidson, since their piracy went well beyond interoperability to copy protected works and interfere with the protected rights of the copyright holder.

\section{THE VIRTUAL O}

Bryce once had high hopes for the benefits of DRM and the opportunities for a micro-economy that could create an economic windfall for the virtual buskers who earned a nickel per play from the celestial jukebox. Pay-per-use systems were heavily discussed at the start of the Internet age. ${ }^{156}$ Judge Easterbrook had a vision of the future:

The concern about high transactions costs is a substantial one, though it diminishes as time passes. Today your computer can negotiate many of these transactions (as it does with DRM software) without your knowing, and micro-payment systems may debit and credit accounts automatically. Technology is moving us toward the world where transactions costs are close to zero, and the Coase Theorem can be a reality rather than a thought experiment. ${ }^{157}$

Even today, there remains some hope for the future of entertainment and literary works. "[O]ften overlooked but at least of equal importance, DRM is intended to lower costs for obtaining content legally. The goal of DRM is to enable and facilitate legal licensing of digital information by

155. See, e.g., Salinger v. Random House, Inc., 811 F.2d 90 (2d Cir. 1987). In Salinger, the defendant violated the user agreements of the libraries of Harvard and Princeton. Id. at 93. The breach of contract resulting in unauthorized access to the copyrighted works did not play any role in the analysis except to assure that the unpublished works had not lost their copyright protection. Id. at 96.

156. See Randal C. Picker, From Edison to the Broadcast Flag: Mechanisms of Consent and Refusal and the Propertization of Copyright, 70 U. CHI. L. REV. 281, 295 (2003) ("Microconsent, as it were, would make it possible to charge users small amounts for small uses, and we could march down the demand curve for a particular work."); Diane Leenheer Zimmerman, Authorship Without Ownership: Reconsidering Incentives in a Digital Age, 52 DePAUL L. REV. 1121, 1126-27 (2003); Yochai Benkler, Freedom in the Commons: Towards a Political Economy of Information, 52 DUKE L.J. 1245, 1254 (2003).

157. Frank H. Easterbrook, Contract and Copyright, 42 Hous. L. REv. 953, 966-67 (2005). 
reducing the transactional costs for consumers to find, access, and use the digital information they demand."158

\section{A. Reinvigorating the Public Domain}

Ironically, the final concern regarding DRM and the attendant loss of consumer respect for copyright may be the potential for the "virtual $O$," the intersection of the public domain, open source entertainment, the creative commons, and the various attempts by authors and artists to exploit the social network capabilities of the new media.

There is no inherent conflict between a robust DRM regime and a robust public domain or shared domain environment. Just as copyright does not eliminate the public domain nor eradicate the First Amendment, the technological measures available to content providers need not further erode these economic and practical necessities. The point is not new.

As more and more copyrighted content is released in digital form, the risk of a
shrinking domain for fair use has inspired some observers to ask whether DRM
technology may evolve to preserve end user freedoms. Under this view, DRM
technology need not be inherently restrictive of fair use rights. Rather, limiting fair
use via DRM is simply one choice among many alternative design decisions that
DRM architects might adopt.

The statute itself takes a small step in this direction. By its terms it does not reach any works in the public domain. "No person shall circumvent a technological measure that effectively controls access to a work protected under this title." 160 Theoretically, works in the public domain such as the Sony Reader classics library have no protection under the DMCA. Of course, aggressive distributors can readily add a bit of copyrighted material to the public domain content and then invoke the DMCA.

The concern has been expressed quite effectively:

As the content marketplace continues to become more digitized, [interest] groups have argued DRM access controls will "creep" into collections of works that not only contain limited portions of copyrighted material, but also contain substantial portions from the public domain as well, in the form of "thin copyrights." Thus, protecting these works with access control mechanisms bolstered by the DMCA could give copyright owners significant control over works that may not be copyrightable. ${ }^{161}$

The fear that nominal works will be used to bootstrap DRM onto public domain works is the somewhat inaccurate aphorism that "you cannot

158. Viktor Mayer-Schönberger, Beyond Copyright: Managing Information Rights with DRM, 84 DENV. U. L. REV. 181, 181-82 (2006).

159. Armstrong, supra note 54 , at 51 .

160. 17 U.S.C. $\S 1201(a)(1)(A)$ (2000) (emphasis added).

161. Eric Matthew Hinkes, Access Controls in the Digital Era and the Fair Use/First Sale Doctrines, 23 SANTA Clara COMPUTER \& High TECH. L.J. 685, 711 (2007). 
copy the copy, you can only copy the original."162 The source of this aphorism proves that the rule is more limited. Judge Learned Hand explained that a second author should not "be free to use the composition of another, who himself has not borrowed." 163 When a work is original to an author, it may be protected by copyright even if an identical work is in the public domain. But if an author incorporates elements from the public domain into a protected work, the materials borrowed from the public domain should never stop being available to all users of that work.

The statute makes clear that DRM does not reach public domain materials, but if DRM is applied to both public domain and protected works, the management system can be enforced. Even though the public domain aspects of a work are free for the taking by subsequent authors, the DRM and the ambiguity regarding the extent of the work's copyright scope may cause a chilling effect. So while some legal solutions to this problem are available, the immediate solution may be a market one.

One response to aggressive digital rights management is an equally aggressive encouragement of the public domain. In this regard, efforts such as the Google book project provide a tremendous social value. All public domain works available to Google are being made available in PDF format. ${ }^{164}$ Project Bartleby ${ }^{165}$ provides a library of free online resources that are selected for their historical and literary importance. Through these and

162. Bleistein v. Donaldson Lithographing Co., 188 U.S. 239, 249 (1903) ("Others are free to copy the original. They are not free to copy the copy."). Judge Learned Hand explained the role of copying the second work as follows:

Any subsequent person is, of course, free to use all works in the public domain as sources for his compositions. No later work, though original, can take that from him. But there is no reason in justice or law why he should not be compelled to resort to the earlier works themselves, or why he should be free to use the composition of another, who himself has not borrowed. If he claims the rights of the public, let him use them; he picks the brains of the copyright owner as much, whether his original composition be old or new. The defendant's concern lest the public should be shut off from the use of works in the public domain is therefore illusory; no one suggests it. That domain is open to all who tread it; not to those who invade the closes of others, however similar.

Fred Fisher, Inc. v. Dillingham, 298 F. 145, 150 (S.D.N.Y. 1924).

163. Dillingham, $298 \mathrm{~F}$. at 150 (emphasis added).

164. See Google Book Search, What You'll See When You Search on Google Books Search, http://books.google.com/intl/en/googlebooks/screenshots.html (last visited May 4, 2008) ("Each book includes an 'About this book' page with basic bibliographic data like title, author, publication date, length and subject. For some books you may also see additional information like key terms and phrases, references to the book from scholarly publications or other books, chapter titles and a list of related books. . . Y You can see books in Full View if the book is out of copyright, or if the publisher or author has asked to make the book fully viewable. The Full View allows you to view any page from the book, and if the book is in the public domain, you can download, save and print a PDF version to read at your own pace.").

165. See Bartleby.com, http://www.bartleby.com (last visited May 4, 2008). 
similar projects, DRM will become irrelevant for published works. Whether there is corporate or charitable support for the same activities in music, television, art, and film remains to be seen. ${ }^{166}$

\section{B. Embracing Open Source Art}

A second response has been the vigorous open source community. In software, open source has proven itself very successful. The web browser Firefox, e-mail client Thunderbird, and teaching platform Moodle are just a few of the highly competitive software programs that claim meaningful market share and provide strong creative leadership in their fields.

In music, experiments in open source musical creation are few and rather trivial. Instead, the music industry has used the technology to empower musicians to self-publish or self-promote their music. While this may have little or no direct financial compensation, it allows musicians and bands to grow their fan base. The bands earn their compensation in live performances. The free music made available to the public is a small loss when compared to the earnings at the bars, clubs, and concert halls.

Although the model of free music distribution has not supplanted the traditional record company recording contract, it is a legitimate alternative for these artists and may reflect the most successful shift in entertainment business models. Fortunately for this model, access to commercial quality sound recording and editing equipment has made the move towards selfpublishing practical. While there may be some difference in production quality, high quality albums can be made without the expenses traditionally associated with the studio recording system. Moreover, since standard record contracts require that the recording artists pay the cost of recording (in the form of recoupable advances), the choice to reduce these expenses also helps protect the musicians from potentially devastating debt owed to recording companies. There are other business implications to this model, such as the lack of promotional funding and radio station air-play support for the album. Nonetheless, for many recording artists, the ability to control their own content and build their own fan base is a desirable and sustainable business model.

Bryce discovered the benefits of a web-based promotional strategy after the first recording contract signed by Bryce resulted in a $\$ 25,000$ liability to a record company that refused to exercise the option on the band's second album. After obtaining a release from the record label, Bryce re-

166. See, e.g., Springfield Township High School Virtual Library, http://www.sdst.org/shs/library/cfimages.html (last visited May 4, 2008) (listing of such resources); Wikimedia Meta-Wiki, Help: Public Domain Image Resources, $\mathrm{http}: / /$ meta.wikimedia.org/w/index.php?title=Help:Public_domain_image_resources\&oldid= 647452 (last visited May 4, 2008) (listing of sources). 
fused to sign with another label, instead writing songs and touring with an unsigned band. Bryce received little radio play but did manage to land one summer tour.

Bryce's band also learned the lesson of the jam band. The band encourages audience members to record the live concerts and trade them online. ${ }^{167}$ The band has a slow but growing following. Bryce often uses the songs of the band to supplement the YouTube clips. Through Facebook, MySpace, and other social networking sites, the band actively promotes its upcoming concerts, posts jam sessions, and even auditioned for a new bass player.

But Bryce wants more. Bryce wants to be a professional author and artist, not a waiter or copywriter.

Bryce has not yet found the vehicle for using Second Life and the online social networks to create a feature-length film. Bryce's documentary experiment, however, was something of a success. Bryce had observed a young audience member being punished by her father. Bryce put out a call on the band's website and on the social networks for kids who felt they were the victims of excessive corporal punishment to answer a short series of questions - on camera. Bryce asked them to film the paddles, belts, or other "tools" used. And of course, Bryce had each person expressly give permission for their personal video logs to be used in the making of Bryce's documentary.

Bryce received forty-seven clips, of which six seemed like hoaxes. After making a rough cut of the documentary, Bryce was told that everything in the documentary should be carefully verified before broadcasting any of it to avoid defamation charges. To Bryce's dismay, after some due diligence, one of the more dramatic clips seemed increasingly unlikely, so Bryce removed it from the documentary. On the other hand, one of the parents interviewed - on camera-was even more forthcoming and compelling than her son, so the due diligence ultimately added content to the finished product.

The use of social networks to help create the documentary footage and highlight this social issue worked quite well for Bryce. A few of the short clips were posted to YouTube with links to the full-length documentary.

Bryce returned to the methodology for a documentary on pollution and the environment, asking the public to videotape examples of waste, garbage dumping, environmental damage, local clean-up efforts, and other related

167. See, e.g., Live Music Archive, http://www.archive.org/details/etree (last visited May 4, 2008) ("etree.org is a community committed to providing the highest quality live concerts in a lossless, downloadable format. . . A All music in this Collection is from tradefriendly artists and is strictly noncommercial, both for access here and for any further distribution. Artists' commercial releases are off-limits." (emphasis omitted)). 
stories. Again, Bryce was able to weave the material into a compelling documentary.

Buoyed by the success of the two documentaries, Bryce created "Socialdocs.org." 168 Bryce not only posted an edited version of the documentary but posted all the original footage. On the site, Bryce explained how to create a compelling and journalistically sound documentary, including the need for verifying all the content before finishing the documentary, and the process (as well as the costs) for adding music. Participants on the website were encouraged to join in on documentaries under development, to suggest new documentary topics, and to edit the submitted footage into finished documentaries. The website participants then voted for the best documentaries on each topic, and those "winners" were offered for commercial distribution in theatres and on television. Through the process, Bryce has become a more thoughtful filmmaker and storyteller.

Bryce still wanted to make feature films. To help get films financed and distributors interested, Bryce actually staged a reading in Second Life. Using the virtual world, actors performed the parts using the animated sets available in the virtual life backdrop to help bring the script to life. It served as a virtual story-board for the film. A few investors were interested, but most were confused by the "animated" nature of the staged reading. Second Life proved far too cumbersome as a platform for script development, but one of the motion picture studios became interested in adapting the approach for internal purposes.

Again, Bryce experimented with additional art forms. Bryce gave up the minstrel character in World of Warcraft for a troubadour Orc, known for heavy metal in both song and blade. The Tales of the Troubadour became something of a cult hit, earning Bryce a great deal of attention online in the role-playing game, a featured appearance at Comic-Con, ${ }^{169}$ and a guest role in a comic book (for the character). As the online role playing and virtual social networks continue to grow and mature into new media, the role of feature films and television may diminish. Feature films will become the opera of the twenty-first century, funded by charitable donors who remember the relevance to their childhood, even though such films are no longer in step with the future. Certainly there are some who still promote silent movies and others who spend their time and effort on black-andwhite films.

168. http://www.socialdocs.org (as of the publication of this Article, the website is not yet active).

169. See Comic-Con Int'l, http://www.comic-con.org/ (last visited May 4, 2008) (the world's largest comic book and science fiction annual convention). 


\section{The Brave New World of the Virtual O}

It may be that Bryce has stepped onto the Virtual $O$, where the wooden stage has given way to a limitless arena, bounded only by the flights of fancy imagined by the programmers, illustrators, and participants in the online world. Can these worlds also sustain a professional class of participants who earn a living at their craft, or will these online environments rely on the volunteer efforts of community theatre players? The medium is far too new to answer that question.

Bryce remains very talented and perpetually relentless. Every age has had its star musicians, writers, artists, and personalities, and every age will have its Euripides, Shakespeare, Bob Dylan, or Steven Spielberg. Bryce hopes to achieve success and join the pantheon. If DRM fails, however, and legitimate protection for copyright wanes, the size of the modern pantheon will shrink, and fewer artists will earn enough to avoid needing a day job. Without any reward for writing short stories, fewer writers will learn their craft to write great novels. Without any professional promotion by record companies, some of the best new music will never be made, encouraged, or heard.

Television and feature films will suffer the most, because they are the media in which it is hardest to do well when one works home alone-even if home alone actually includes a social network of thousands. On the other hand, perhaps the need for DRM is less relevant for television and motion pictures. Members of the public recognize the economic value and consequences of pirating television and feature films in a way that may dissuade them from copying those works, even though the same person would not hesitate to copy songs from a friend. ${ }^{170}$ If so, then perhaps there is hope for the motion picture industry despite fears of download efficiency.

Apple CEO Steve Jobs's suggestion that DRM has already failed may be too precipitous as well as too self-serving. If the public perceives a different obligation to respect the content of film and television, then the solution is to follow Jobs's recommendation that DRM be eliminated from music, specifically to further distinguish songs from movies, television, and software where DRM has a more significant role.

The Copyright Act itself is based on fundamentally different treatment of music than other media. Sections 114 and 115 treat music and sound recordings as sui generis. ${ }^{171}$ The old jukebox license, copyright royalty tribunals, and other aspects of the statute reflect the vastly different social expectations placed on music. No painter would allow "covers" where

170. It is entirely plausible that the copying of a $\$ 1.00$ song is considered socially $d e$ minimis.

171. 17 U.S.C. $\S \S 114-15(2000)$. 
other artists were able to reprint the work by paying a statutory rate, nor would any novelist or sculptor. Music, therefore, is different.

Judge Easterbrook would argue that the market transactions should be the source of variation rather than the statute: ${ }^{172}$

A standards-setting organization could prescribe, say, 20 different copying rulessets of permission and payment terms. There may be competing organizations, with their own standards. Each Internet server and client would understand these terms and carry out the negotiation automatically, remitting any payment to an agreed depository by secure methods. ${ }^{173}$

Whether the default rules should come exclusively from contracts or whether the Copyright Act has a significant default rule-setting function remains open for debate. Whichever the source, the ability for the public to pay for a menu of rights associated with a particular work is no longer merely a theoretical suggestion.

Apple has already introduced such a model by selling DRM-free versions of songs on iTunes for $\$ 1.29$, a thirty percent premium over Apple's proprietary DRM protocol. ${ }^{174}$ Moreover, Steve Jobs was correct in his letter about DRM for his iPods. He has built a business model designed to exploit the failures in the music industry and has done so brilliantly. iPods and iPhones take advantage of the content from ripped CDs and from illegally shared downloads even as Jobs negotiated a license for lawful music that goes much closer to the expectations of the consumer in the appropriate number of copies and devices. ${ }^{175}$ In this way, the license co-opts the con-

172. Easterbrook, supra note 157 , at 972.

173. Id.

174. iTunes Plus, http://www.apple.com/legal/itunes/us/sales.html (last visited May 4, 2008). See also http://phobos.apple.com/WebObjects/MZStore.woa/wa/iTunesPlusFAQPage.

175. See, e.g., iTunes Store Terms of Service, If 9.b, http://www.apple.com/legal/itunes/us/service.html (last visited May 4, 2008):

b. Use of Products. You acknowledge that Products . . contain security technology that limits your usage of Products to the following applicable Usage Rules, and, you agree to use Products in compliance with the applicable Usage Rules.

Usage Rules

(i) Your use of the Products is conditioned upon your prior acceptance of the terms of this Agreement.

(ii) You shall be authorized to use the Products only for personal, noncommercial use.

(iii) You shall be authorized to use the Products on five Apple-authorized devices at any time,....

(iv) You shall be able to store Products from up to five different Accounts on certain devices, such as an iPod, . . . at a time; ....

(v) You shall be authorized to burn an audio play list up to seven times.

(vi) You shall not be entitled to burn Video Products ....

(vii) You shall be entitled to export, bum (if applicable) or copy (if applicable)

Products solely for personal, noncommercial use. 
sumer. By drafting the license to reflect behavior, we can more easily flag the egregious offenses rather than shout blindly as a thronging mob breaks our rules. Jobs has understood consumer behavior far better than the record companies, in part because Apple can benefit from these behaviors while the record companies can only fashion policies to limit the damage.

\section{CONCLUSION}

The DMCA remains a modestly effective weapon for disarming the most egregious circumvention products and stabbing the most aggressive pirates. Courts yield the statute like a dull blade, effective only at close range. The tip can only prick a tiny fraction of the infringers, and few are intimidated.

Despite the limited practical effect on access to circumvention technology, the cases help clarify the law and the illegal nature of DeCSS, software designed to thwart Macrovision, and similar black box technologies. Such cases help the MPAA police the marketplace. To the extent that WalMart, Target, and Best Buy continue to dominate retail sales, the litigation and the statute keep the store shelves clear of circumvention technology.

Unfortunately, the hijacking of the DMCA by consumer goods manufacturers such as Lexmark and Chamberlain has further eroded the credibility of the law. Using the statute as a shield against legitimate market competition is so obviously beyond the intent of Congress that it should not have required the finely-crafted court decisions presently addressing the issue. Unless courts begin to broadly reject these claims because the goods being sold are not works under the Copyright Act, manufacturers will inevitably mirror their software to match the court's opinions. Courts need not allow the manufacturers to free-ride on the software protection. Neither Congress nor WIPO were ambiguous regarding the scope of these protections. If the courts err by denying too many claims for protection, Congress can weigh in to adjust the balance, but the starting point should be the scope of the statute as contemplated when it was adopted internationally through WIPO and implemented by Congress. Nowhere were garage doors or computer toner cartridges discussed as needing anti-piracy legislation.

Beyond the problem caused by the manufacturers remains the problem caused by the software companies' clickwrap and shrinkwrap agreements. Again, the congressional compromises identified in the statute are more

(ix) Any burning (if applicable) or exporting capabilities are solely an accommodation to you and shall not constitute a grant or waiver (or other limitation or implication) of any rights of the copyright owners in any audio or video content, sound reId. cording, underlying musical composition, or artwork embodied in any Product. 
reasonable than the court opinions regarding those provisions. Since Section 1201(f) provides for reverse-engineering for purposes of interoperability, the copyright owner should not be able to impose contract terms that strip the public of this opportunity. It is precisely because the technology exists to completely control the distribution of the copyrighted work that digital rights management is regulated by the DMCA, and when that regulation includes exceptions, those exceptions should be given due weight.

But we must learn from the shrewd lessons of Mr. Jobs. If DRM is worth saving - and I believe it is artistically and socially imperative to do so if we hope to stop the wasteland from spreading to the Internet, the movie house, and the bookstore - then we must reform its use.

The purveyors of media protected by DRM must stop railing at the public and begin to conform their expectations to the expectations of the public as part of the effort to find an enforceable and defensible line in the sand. For example, the RIAA should always have had a system that included pre-litigation fact finding to assure that hard core pirates were the target, not casual users or the wrong parties. For software, interoperability should be a fair use, and fair use must be explicitly made an affirmative defense to Section 1201. Similarly, the work protected by DRM must substantially be protected under copyright and provide no DMCA protection to collections of public domain works, consumer electronics, or other products outside the original intent of the statute. The DVR (i.e., TIVO) must always allow fast forwarding and rewinding through any content, whether it be commercials, programming, or even the FBI warning. Finally, to find a compromise with the public, best practices in licensing should mirror that of Apple, so that consumer usability, interoperability, and convenience are not done away with.

A decade after WIPO mandated anticircumvention and digital rights management, there has been some modest success with the statute, but much work remains to be done. Once again, I must ask whether the fight against piracy would be significantly different had Chapter 12 not been adopted. The answer is not a resounding yes.

Ten years later, the DMCA has offered only a modest start on the road to addressing piracy. When I see a landscape without the ability to enforce copyright, I fear the spread of the wasteland. If the DMCA can help us to craft the argument for copyright protection, it needs to be used in moderation and enforced without overreaching. If not, the cacophony of voices calling for its demise will drown out the music and artistry of those Congress sought to protect.

The stage is set, but the final act is not yet written. 